PAPER • OPEN ACCESS

Characterization and beneficiation of Ethiopian kaolin for use in fabrication of ceramic membrane

To cite this article: Tsegahun Mekonnen Zewdie et al 2021 Mater. Res. Express 8115201

View the article online for updates and enhancements.
You may also like

- $\frac{\text { Application Prospect of Ceramic }}{\text { Membrane Coupling Process in Refinery }}$
$\frac{\text { Wastewater }}{\text { R Z Cheng, L P Qiu, G C Liu et al. }}$
- Surface states and persistent photocurrent
$\frac{\text { in a GaN heterostructure field effect }}{\text { transistor }}$
A Horn, O Katz, G Bahir et al.
- Development of flat ceramic membrane
$\underline{\text { technology on municipal wastewater }}$
$\frac{\text { treatment }}{\text { Qi Qiu, Bao wei Zhao and Li ping Qiu }}$

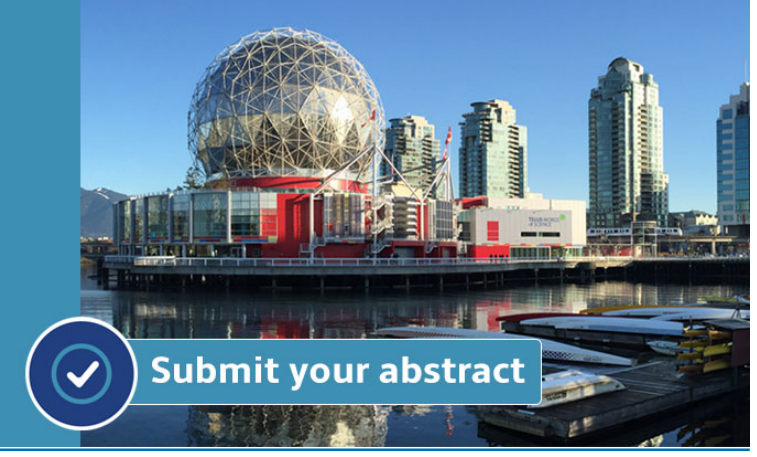




\section{Characterization and beneficiation of Ethiopian kaolin for use in fabrication of ceramic membrane}

RECEIVED

17 July 2021

REVISED

10 October 2021

ACCEPTED FOR PUBLICATION

13 October 2021

PUBLISHED

2 November 2021

Original content from this

work may be used under

the terms of the Creative

Commons Attribution 4.0

licence.

Any further distribution of this work must maintain

attribution to the

author(s) and the title of

the work, journal citation

and DOI.

\author{
Tsegahun Mekonnen Zewdie ${ }^{1,3}$ (i), Indah Prihatiningtyas ${ }^{3,4}$, Abhishek Dutta $^{2}$, Nigus Gabbiye Habtu ${ }^{1}$ and \\ Bart Van der Bruggen \\ 1 Bahir Dar University, Faculty of Chemical and Food Engineering, Department of Chemical Engineering, Bahir Dar, Ethiopia \\ 2 Izmir Institute of Technology, Department of Chemical Engineering, Gülbahçe Campus, Urla, Izmir 35430, Turkey \\ 3 KU Leuven, Department of Chemical Engineering, Faculty of Engineering, Celestijnenlaan 200F, B-3001 Leuven, Belgium \\ ${ }^{4}$ Department of Chemical Engineering, Mulawarman University, Jalan Sambaliung No.9, Sempaja Selatan, Samarinda, Kalimantan \\ Timur, Indonesia \\ E-mail: tsegmek@gmail.com
}

Keywords: kaolin, beneficiation, oxalic acid, iron oxide, ceramic membrane

\section{Abstract}

Kaolin (china clay) is a rock material that is very rich in kaolinite. A kaolin ore from Debre Tabor, Ethiopia containing $59.2 \mathrm{wt} \% \mathrm{SiO}_{2}, 24.9 \mathrm{wt} \% \mathrm{Al}_{2} \mathrm{O}_{3}, 2.4 \mathrm{wt} \% \mathrm{Fe}_{2} \mathrm{O}_{3}$ and $8.22 \mathrm{wt} \%$ loss on ignition (LOI) was physically beneficiated, chemically leached, and thermally treated for possible industrial use, especially for ceramic membrane fabrication. The leaching experiments were carried out using oxalic acid solutions as leaching reagents for the iron extraction process. The effect of acid concentration, reaction temperature, and contact time on iron leaching was investigated. It was determined that the rate of iron extraction increased with the oxalic acid concentration, leaching temperature, and contact time. A substantial reduction of iron oxide ( 2.4 to $0.36 \mathrm{wt} \%)$ from the raw kaolin was observed at operating conditions of $2.0 \mathrm{M}$ oxalic acid, the temperature of $120^{\circ} \mathrm{C}$, and contact time of $120 \mathrm{~min}$. A maximum kaolin whiteness index of $81.4 \%$ was achieved through this leaching process. Finally, the physically beneficiated, chemically leached, and thermally treated kaolin raw material was used to fabricate a low-cost kaolin-based ceramic membrane. After firing at $1100^{\circ} \mathrm{C}$ the ceramic membrane was found to have a mass loss of $11.04 \pm 0.05 \%$, water absorption of $8.9 \pm$ $0.4 \%$, linear shrinkage of $14.5 \pm 0.05 \%$. It was demonstrated to be chemically stable, having less than $3 \%$ mass loss in acid solution, and less than $1 \%$ mass loss in alkali solution. The newly developed membranes have thus properties comparable to commercial ceramic membranes.

\section{Introduction}

One such abundant and inexpensive geomaterial for ceramic membrane fabrication is kaolin [1]. Kaolin (china clay) is a rock material that is rich in kaolinite. Kaolinite is a common hydrous aluminosilicate mineral found in sediments, soils, and sedimentary rocks, with chemical compositions of $\mathrm{Al}_{2} \mathrm{Si}_{2} \mathrm{O}_{5}(\mathrm{HO})_{4}$. Kaolinite normally appears as stacked pseudo hexagonal platelets, with a common booklet-like shape. Each kaolinite layer is considered as a strong dipole, where the siloxane surface is hydrophobic and dominated by negative charges, while the aluminum surface exhibits positive charges and is hydrophilic. Thus, the individual layers of kaolinite are strongly bonded with hydrogen and dipolar interactions. The key properties of kaolin are opacity, electrical and mechanical property, whiteness and brightness, and particle shape and size distribution [2].

Ethiopia has a huge reserve of kaolin (20 Million tons), which spreads in different parts of the country such as Tigray, Amhara, Oromia and Southern Nations, Nationalities, and Peoples Regions, but mining at depth, continuous and progressive research on kaolin deposits and their occurrences, an increased level of mineral impurities make commercial applications not viable [3]. The major impurities in kaolin are quartz, mica, feldspar, and iron oxide minerals. To improve the quality of kaolin deposits to possibly meet some industrial 
requirements, the coloring impurities (mainly iron oxides and other small amounts of fluxing components) must be removed through efficient, economical, and environmentally friendly beneficiation methods.

Beneficiation is an upgrading process that is removing mineral impurities such as feldspar, quartz, mica, muscovite, iron oxide, titanium oxide, and clay. Many beneficiation techniques can be used for upgrading the quality and the production of a desired particle shape and size distribution of kaolin clay. The most widely applied physical beneficiation techniques are magnetic [4], flotation [5-7], gravity separation [7], and selective flocculation [8].

Chemical beneficiation methods involve the removal of mineral impurities from kaolin clay by organic and inorganic acids such as oxalic acid [9-15], citric acid [16, 17], thiourea dioxide [18], sodium dithionite [19], sulfuric acid [20-22], and hydrochloric acid [13]. The effect of different organic acids and their concentration in iron removal from kaolin ore has been reported by Saikia et al [17]. Results indicate that the iron removal efficiency of oxalic acid is the most promising organic acid. Similarly, Lee et al [23] reported that oxalic acid solution is the best iron leaching reagent because of its acid strength, good complexing characteristics, and high reducing and bleaching power over those of other organic acids leachants (malonic, citric, and ascorbic acid). Due to the relatively low cost, availability, and very good potential for industrial applications, oxalic acid was chosen as a leachant for the leaching experiments in this work.

In recent decades, biological beneficiation methods have been also used to remove mineral impurities from kaolin clay. Several studies have been applied biological beneficiation techniques for removing mineral impurities from kaolin clay by using different kinds of fungi [24-26] and bacteria [27-29]. Biological purification techniques are more economical, eco-friendly, not energy-intensive, and maintains the crystal structure of kaolin clay to a large extent [30,31] but a very slow process for industrial mass production.

Numerous researchers have studied the beneficiation and characterization of kaolin minerals in order to use as an adsorbent [32, 33], as a filler [34], as a pharmaceutical excipient [35] and as a starting material for the production of refractories [36] and ceramic bodies [37-42]. However, the selection of the most suitable beneficiation technique depends on the amount and type of mineral impurities present. Hence, the beneficiation process applicable to one type of clay may not be appropriate for another [43]. This may involve physical, chemical, and thermal beneficiation techniques which alter the mineral composition, the crystalline structure, surface functional groups, and the specific surface area of clay. It is therefore important to improve the quality of kaolin clays to possibly meet ceramic industry requirements. Although very limited studies on the synthesis and characterization of Ethiopian kaolin have been reported in the literature [3, 32, 44], ceramic properties of Debre Tabor kaolin have not been studied. In order to fill this research gap, the present study was carried out to determine the characteristics of the kaolin clays and examine the ceramic membrane properties.

Compared to polymeric membranes, ceramic membranes can withstand harsh environments due to their high thermal stability, high chemical stability, excellent mechanical strength, biocompatibility, durability, energy efficiency, availability, and sustainability [45]. These excellent properties make ceramic membranes a primary candidate to be used for water treatment and desalination applications. Many studies have been reported to explore ceramic membrane applications for membrane-based water purification techniques such as reverse osmosis [46, 47], forward osmosis [48, 49], pervaporation [50], electrodialysis [51], and membrane distillation [52-55].

The present study is aimed to characterize the kaolin mineral found in a deposit of Debre Tabor in the Amhara region, Ethiopia, to beneficiate the kaolin mineral sample and characterize the beneficiated kaolin, to promote the beneficiated kaolin for the manufacture of low-cost kaolin-based ceramic membranes for water treatment and desalination application.

\section{Experimental method}

\subsection{Materials}

The studied crude kaolin was collected from the local area, Debre Tabor Town, located in the state of the Amhara Region, Ethiopia. Over 5 million tons of kaolin deposit occurs at Debre Tabor [3]. Laboratory grade chemicals, such as sodium hexametaphosphate, oxalic acid, hydrochloric acid, sodium hydroxide, and iron standard solution were used for the present study. To avoid cross-contamination among different samples or from other sources de-ionized water was used for the present study.

\section{Methods}

\subsection{Beneficiation of crude kaolin}

Debre Tabor kaolin ore was beneficiated to improve its silicon oxide $\left(\mathrm{SiO}_{2}\right)$ and aluminum oxide $\left(\mathrm{Al}_{2} \mathrm{O}_{3}\right)$ by removing mineral impurities (feldspar, quartz, mica, muscovite, iron oxide, titanium oxide, and clay) with a 


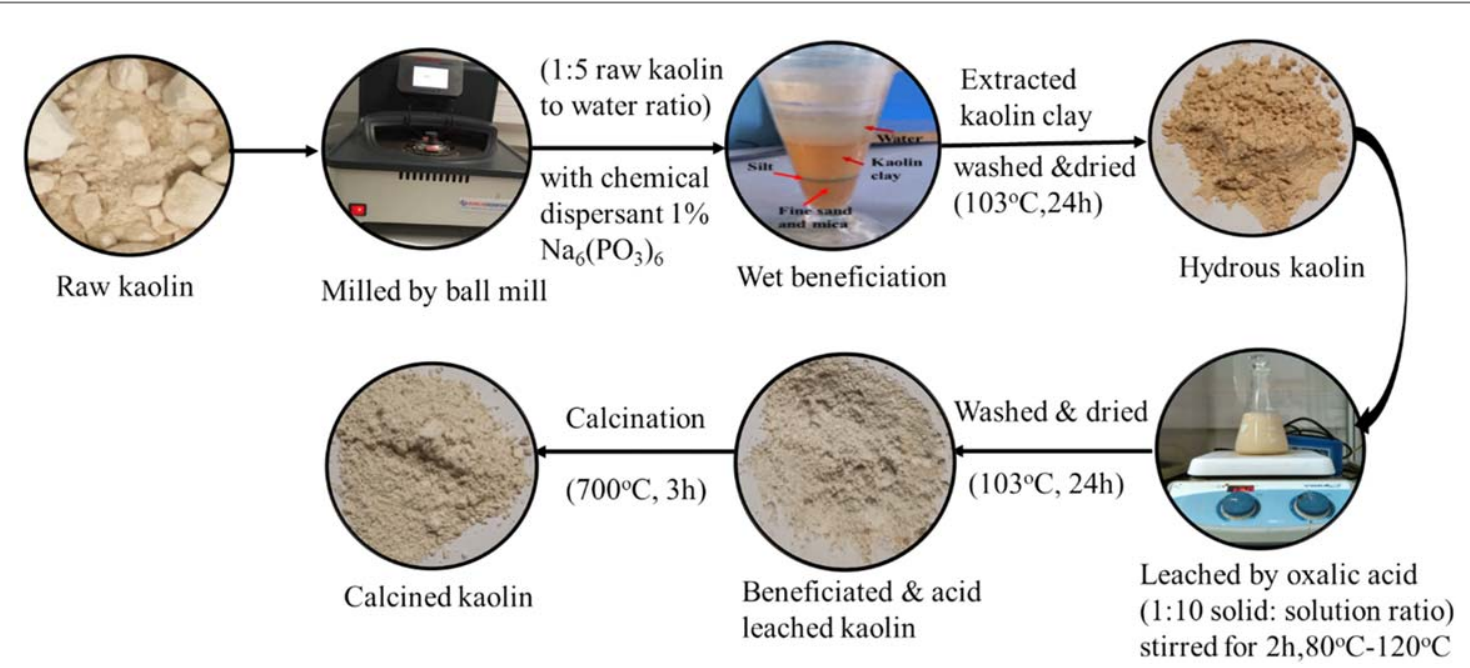

Figure 1. Beneficiation process of debre tabor kaolin clay.

sequential beneficiation process. Some of the course impurities were removed from crude kaolin by physical separation of dirt, followed by milled using a ball milling machine and screened through a $45 \mu \mathrm{m}$ mesh sieve [33].

Then, the crude kaolin was suspended in deionized water (1:5 kaolin to water ratio) in the presence of a chemical dispersant ( $1 \%$ of sodium hexametaphosphate, $\left.\mathrm{Na}_{6}\left(\mathrm{PO}_{3}\right)_{6}\right)$ and then stirred manually for 10 min using a glass rod and allowed to stand for $48 \mathrm{~h}$. The dispersed clay was settled by gravity and fractionated into three layers: the first layer was kaolin clay (top); the second layer was silt (middle), and the third layer was fine sand and mica (bottom). The water was decanted and the kaolin clay was separated from leached clay and dried in an oven at $103^{\circ} \mathrm{C}$ for $24 \mathrm{~h}$ to obtain the beneficiated hydrous kaolin.

\subsubsection{Leaching hydrous kaolin by oxalic acid}

The leaching experiments were carried out in a $300 \mathrm{ml}$ round bottom flask placed in a magnetic stirrer hot plate with temperature control. The hydrous kaolin material was mixed with the oxalic acid solution at different concentrations $(0.1 \mathrm{M}, 0.5 \mathrm{M}, 1.0 \mathrm{M}, 1.5 \mathrm{M}$, and $2.0 \mathrm{M})$ at a $1: 10$ solid to solution ratio and maintained at different targeted temperature $\left(80^{\circ} \mathrm{C}, 90^{\circ} \mathrm{C}, 100^{\circ} \mathrm{C}\right.$, and $\left.120^{\circ} \mathrm{C}\right)$ for $2 \mathrm{~h}$ under continuous moderate stirring (300 rpm). A $10 \mathrm{ml}$ slurry sample was taken every 20 minutes till the reaction time of $120 \mathrm{~min}$. it was filtered using a nylon syringe filter with a porosity of $0.2 \mu \mathrm{m}$ then centrifuged immediately at $1000 \mathrm{rpm}$ for $10 \mathrm{~min}$. Since the resulting solution is a higher concentration, a 1:100 dilution was used for the subsequent analysis. The clear diluted solution was analysed for iron content by Inductively Coupled Plasma Optical Emission Spectroscopy (ICP-OES, Optima 2100 DV, Perkin Elmer Instruments, Shelton, CT, USA). A wavelength of $238.204 \mathrm{~nm}$ was used for iron detection but an alternative wavelength was also used for controlling possible interferences from other elements (239.562 nm) [56]. All experiments were performed in triplicate, all data are expressed as the mean \pm standard deviation.

The residue product was then filtered, repeatedly washed with distilled water to remove any unspent oxalic acid, dried at $103^{\circ} \mathrm{C}$ for $24 \mathrm{~h}$. Finally, the acid-treated hydrous kaolin was activated through thermal treatment in a muffled furnace at $700{ }^{\circ} \mathrm{C}$ for $3 \mathrm{~h}$, resulting in the formation of calcined kaolin (see figure 1 ). Its transformation to metakaolin, an amorphous Al-Si phase from which aluminum is easily leached by acid leachants (sulfuric, hydrochloric and, oxalic acid) [57, 58]. According to the previous studies [13, 32, 57], physical beneficiation and calcination were widely applied first and then followed by leaching with acid. In this study, the physical beneficiation and leaching with oxalic acid were applied first and then followed by calcination. In order to remove a high level of iron oxides from kaolin clay, chemical leaching of the clay prior to high-temperature calcination was applied. Moreover, leaching with oxalic acid before calcination is important to prevent the extraction of aluminum from kaolin through the oxalic acid leaching process. Another study proves that the structural ferric ions and ferric oxides from kaolin were difficult to remove using acid as a leaching reagent; therefore, iron removal by acids should be conducted prior to calcination [13].

\subsection{Characterization of kaolin clay}

The particle size distributions of kaolin were determined by the laser diffraction particle size analyser (Mastersizer 3000, Malvern Instruments, UK) using water as dispersing medium. The kaolin powder 
morphology, as well as the microstructure formed in the sample, was examined using a Scanning Electron Microscope (JEOL, JSM-6010LV, Tokyo, Japan). The $\mathrm{pH}$ of the aqueous suspension was determined using a benchtop pH meter (Mettler Toledo Seven Compact ${ }^{\mathrm{TM}} \mathrm{pH} /$ Ion meters S220, Switzerland). The specific surface area, pore-volume, and pore diameter of kaolin powder were measured using surface area and pore size analyzer (Model Nova 2000e, USA).

Thermal Analyses (DSC/TGA, Model Q600, TA Instruments, USA) were used to analyze the thermal behavior of kaolin clay. The method of Wavelength Dispersive x-ray Fluorescence (WD-XRF, Philips PW 2400, Almelo, The Netherlands) spectrometers elemental analyses of clays has been continuously showing the class of alumino-silicates to which the analyzed material corresponds. The elements determined in clays have been presented as a relative percentage of the elements expressed as oxides in the whole sample. The identification of the crystalline phases was carried out by x-ray Diffraction (XRD, D2 phaser, Bruker, Germany) using Cu-Ka 1 radiation at a scanning rate of $2^{\circ} \mathrm{min}^{-1}$. Fourier Transform Infrared (FTIR) spectroscopy (Perkin Elmer Spectrum 100, USA) over the range of 4000 to $400 \mathrm{~cm}^{-1}$ was used to measure kaolin powder OH-stretching and bending vibration modes.

\subsubsection{Loss on ignition test (LOI)}

The loss on ignition was determined using the expression equation (1).

$$
\text { LOI }=\frac{M_{2}-M_{1}}{M_{2}-M_{3}}
$$

Where $M_{1}$ is the weight of empty crucible; $M_{2}$ is the weight of crucible and sample before calcination; $M_{3}$ is the weight of crucible and sample after calcination.

\subsection{Preparation and characterization of the membranes}

Preparation of ceramic membranes and testing of the samples was done on laboratory scale. To evaluate the suitability of beneficiated kaolin clay properties for ceramic membrane, flat green bodies were used. A flat green body was prepared using beneficiated kaolin (without any reactive additives) by a dry pressing machine (Enerpac Hydraulic Press, Model RC50, USA) at a pressure of $4.6 \times 10^{2}$ bar for $5 \mathrm{~min}$. The flat green specimens were cut into a rectangular shape ( $20 \mathrm{~mm}$ long by $20 \mathrm{~mm}$ wide) with a thickness of $1 \mathrm{~mm}$. The test specimens were dried in an oven at $110^{\circ} \mathrm{C}$ for $24 \mathrm{~h}$ and then fired at $500^{\circ} \mathrm{C}, 600^{\circ} \mathrm{C}, 700{ }^{\circ} \mathrm{C}, 800{ }^{\circ} \mathrm{C}, 900{ }^{\circ} \mathrm{C}, 1000^{\circ} \mathrm{C}$, and $1100{ }^{\circ} \mathrm{C}$ for 1 h using a laboratory furnace (Nabertherm P330 Muffle Furnace, Germany). The sintered sample was ready for analysis of various physical properties (mass loss, linear shrinkage, water absorption, porosity, wettability, chemical stability, and surface morphology). All tests were performed in triplicate, all data are expressed as the mean \pm standard deviation.

\subsection{Mass loss}

Mass losses of the flat ceramic bodies were calculated according to equation (2).

$$
\text { Mass loss }=\left(\frac{M_{110}-M_{T}}{M_{110}}\right) \times 100
$$

In equation (2), $\mathrm{M}_{110}$ is the flat ceramic body mass at $110^{\circ} \mathrm{C}$ or dry clay mineral sample, $\mathrm{M}_{\mathrm{T}}$ is the flat ceramic body masses fired to final temperature $\mathrm{T}\left(1100^{\circ} \mathrm{C}\right)$.

\subsubsection{Linear firing shrinkage}

The flat green ceramic bodies prepared previously were dried in an oven at $110^{\circ} \mathrm{C}$ for $24 \mathrm{~h}$ and fired to a final temperature of $500{ }^{\circ} \mathrm{C}, 600^{\circ} \mathrm{C}, 700{ }^{\circ} \mathrm{C}, 800{ }^{\circ} \mathrm{C}, 900^{\circ} \mathrm{C}, 1000^{\circ} \mathrm{C}$, and $1100{ }^{\circ} \mathrm{C}$ for $1 \mathrm{~h}$. The shrinkage percentage that occurred during the firing process was determined using the dimensions (volume) of the flat green ceramic specimen before and after the firing process. The total linear shrinkage percentage of the flat green kaolin-based ceramic specimen was determined by using equation (3).

$$
\text { Total linear shrinkage }=\left(\frac{V_{0}-V_{f}}{V_{o}}\right) \times 100
$$

where $V_{o}$ is the volume of the specimen before firing and $V_{f}$ is the volume specimen after firing.

\subsubsection{Water absorption and porosity}

Water absorption and porosity of the flat ceramic specimens were determined by the boiling water method. The flat ceramic specimens prepared in the linear shrinkage part and sintered to different final temperatures ranging from $500^{\circ} \mathrm{C}$ to $1100^{\circ} \mathrm{C}$ were immersed in boiling water for $2 \mathrm{~h}$ and cooled to room temperature. After boiling the specimens were immersed in water for $24 \mathrm{~h}$ and then the surface was wiped with tissue paper. The percentage 


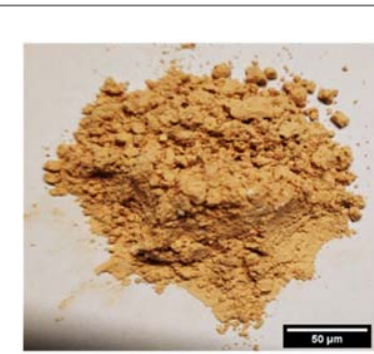

a)

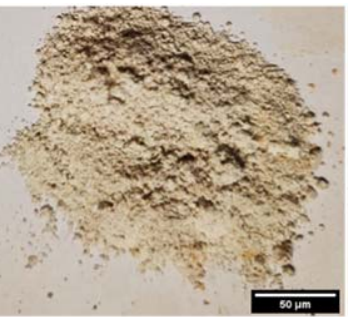

b)

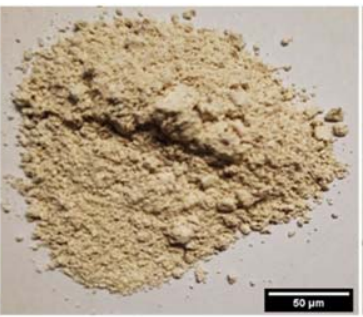

c)

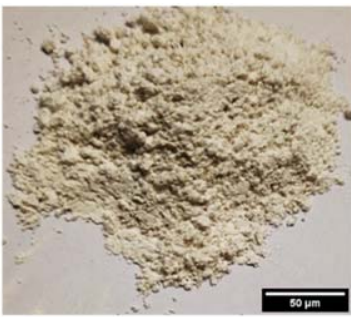

d)

Figure 2. Samples of (a) raw kaolin; (b) beneficiated and acid leached kaolin; (c) beneficiated, acid leached and calcined kaolin; (d) commercial kaolin.

of water absorption was evaluated using the expression equation (4).

$$
\text { Water absorption }=\left(\frac{M_{s}-M_{d}}{M_{d}}\right) \times 100
$$

where $M_{s}$ is the mass of the saturated specimen, $M_{d}$ is the mass of the dry specimen.

The porosity of the flat ceramic body was evaluated using the expression equation (5).

$$
\text { Porosity }=\left(\frac{\frac{M_{s}-M_{d}}{\rho_{w}}}{V_{f}}\right) \times 100
$$

where $M_{d}$ is the mass of the dry specimen ( $g$ ), $M_{s}$ is the mass of the saturated specimen $(\mathrm{g}), \rho_{\mathrm{w}}$ is the density of water $\left(1 \mathrm{~g} \mathrm{~cm}^{-3}\right.$ at $\left.4{ }^{\circ} \mathrm{C}\right)$, and $\mathrm{V}_{\mathrm{f}}$ is the volume of the fired specimen $\left(\mathrm{cm}^{3}\right)$.

\subsubsection{Contact angle measurement}

Contact angle measurement has been performed on ceramic specimens to evaluate their surface hydrophilic characteristics. The wettability properties of flat ceramic specimens fired to different final temperatures ranging from $500{ }^{\circ} \mathrm{C}$ to $1100^{\circ} \mathrm{C}$ were measured by the sessile drop method (Kruss DSA 10Mk2, Germany) using distilled water at room temperature. All contact angle readings were taken $10 \mathrm{~min}$ after a $0.5 \mathrm{ml}$ water droplet was placed on the membrane surface.

\subsubsection{Chemical stability test}

Chemical resistance tests were carried out in an acidic or basic environment. A flat ceramic specimen fired at different temperature $\left(500{ }^{\circ} \mathrm{C}, 600{ }^{\circ} \mathrm{C}, 700^{\circ} \mathrm{C}, 800^{\circ} \mathrm{C}, 900^{\circ} \mathrm{C}, 1000^{\circ} \mathrm{C}\right.$, and $\left.1100{ }^{\circ} \mathrm{C}\right)$ was immersed in acid solution (hydrochloric acid solutions at $\mathrm{pH}=1.0$ and alkali solution (sodium hydroxide solutions at $\mathrm{pH}=13.0$ ) at ambient temperature for $24 \mathrm{~h}$. The flat ceramic specimens were removed from the solutions (acid and alkali), rinsed with distilled water, and dried in an oven at $110^{\circ} \mathrm{C}$ for $24 \mathrm{~h}$. The weight of the flat ceramic specimen was measured before and after the test and the chemical resistance of the specimen was calculated by the following equation (6).

$$
\text { Chemical resistance }=\left(\frac{M_{0}-M_{\mathrm{pH}}}{M_{0}}\right) \times 100
$$

where $\mathrm{M}_{\mathrm{o}}$ is the mass of the specimen before $\mathrm{pH}$ attack and, $\mathrm{M}_{\mathrm{pH}}$ is its mass after removing the specimen from the acidic $(\mathrm{HCl}, \mathrm{pH}=1.0)$ or basic $(\mathrm{NaOH}, \mathrm{pH}=13.0)$ solutions.

\section{Results and discussion}

\subsection{Material characterization}

\subsubsection{Physical properties of kaolin clay}

The density of the beneficiated kaolin is $2.64 \mathrm{gcm}^{-3}$ as compared to $2.5 \mathrm{gcm}^{-3}$ for the raw kaolin (see table 1). This weight increase may be due to an increase in $\mathrm{Al}_{2} \mathrm{O}_{3}$ content from 24.9 to 29.4\% during the beneficiation process. The $\mathrm{pH}$ values of the raw, beneficiated \& acid leached, beneficiated, acid leached and calcined, and commercial kaolin were 5.85, 5.05, 5.15, and 5.41, respectively. This showed that the surface of the raw, beneficiated \& acid leached, beneficiated, acid leached and calcined, and commercial kaolin body is slightly acidic. Similar results are reported in the literature [33] for raw and beneficiated kaolin. 


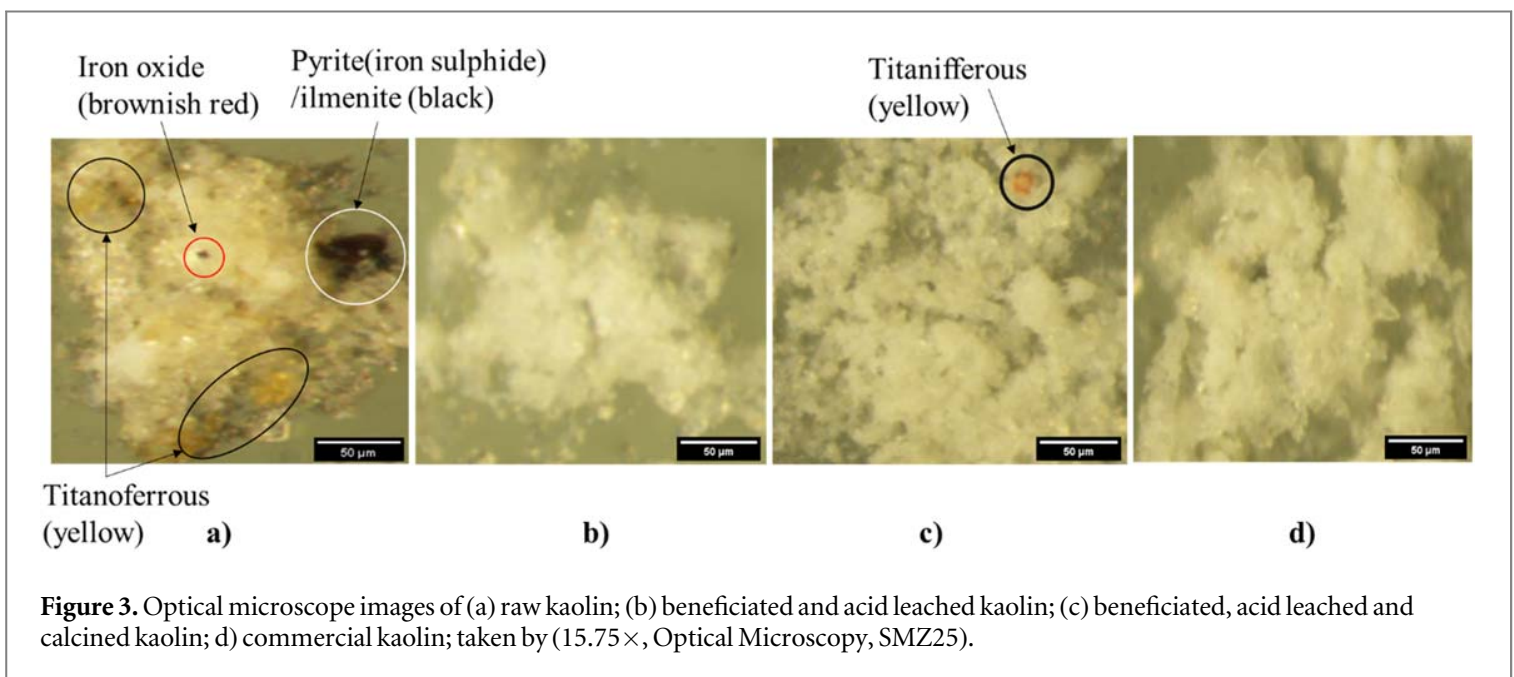

Table 1. Physical characteristics of raw, beneficiated and acid leached, beneficiated, acid leached and calcined kaolin, and commercial kaolin.

\begin{tabular}{|c|c|c|c|c|}
\hline Characteristic & RK & BALK & BALCK & CK \\
\hline Density $\left(\mathrm{g} \mathrm{cm}^{-3}\right)$ & 2.5 & 2.64 & 2.64 & 2.66 \\
\hline $\mathrm{pH}$ & 5.85 & 5.05 & 5.14 & 5.41 \\
\hline \multicolumn{5}{|l|}{$\begin{array}{l}\text { Particle size distribu- } \\
\text { tion (\%) }\end{array}$} \\
\hline $\mathrm{D}_{10}, \mu \mathrm{m}$ & 3.52 & 3.37 & 3.7 & 2.50 \\
\hline $\mathrm{D}_{50,} \mu \mathrm{m}$ & 10.8 & 10.6 & 11.4 & 6.62 \\
\hline $\mathrm{D}_{90,}, \mu \mathrm{m}$ & 45.0 & 30.7 & 42.3 & 21.5 \\
\hline Whiteness Index (ISO) & 72.0 & 81.4 & 79.2 & 88.14 \\
\hline Texture & Fine & Finer & Finer & $\begin{array}{l}\text { Very } \\
\text { finer }\end{array}$ \\
\hline $\begin{array}{l}\text { Specific Surface Area } \\
\qquad\left(\mathrm{m}^{2} \mathrm{~g}^{-1}\right)\end{array}$ & 11.6 & 30.5 & 19.4 & 12.1 \\
\hline Pore volume $\left(\mathrm{cc} \mathrm{g}^{-1}\right)$ & 0.025 & 0.029 & 0.034 & 0.033 \\
\hline Pore size $(\AA)$ & 20.6 & 14.9 & 19.5 & 19.4 \\
\hline
\end{tabular}

RK: Raw Kaolin; BALK: Beneficiated and Acid Leached Kaolin; BALCK:

Beneficiated, Acid Leached, and Calcined Kaolin; CK: Commercial Kaolin.

The particle size distribution of raw, beneficiated \& acid leached, beneficiated, acid leached \& calcined, and commercial kaolin is mainly in the range of 3.52-45 $\mu \mathrm{m}\left(\mathrm{D}_{50}=10.8 \mu \mathrm{m}\right), 3.37-30.5 \mu \mathrm{m}\left(\mathrm{D}_{50}=10.6 \mu \mathrm{m}\right)$, 3.7-42.3 $\mu \mathrm{m}\left(\mathrm{D}_{50}=11.4 \mu \mathrm{m}\right)$, and $0.48-0.99 \mu \mathrm{m}\left(\mathrm{D}_{50}=0.8 \mu \mathrm{m}\right)$, respectively. The slight decrease of particle size of the beneficiated sample compared to the raw kaolin size is due to the dissolution of the iron oxides and oxyhydroxides. There is a substantial increase in particle size of the beneficiated, leached, and calcined sample compared to the raw, beneficiated, and leached kaolin as a result of calcination. According to these results, the particle sizes of beneficiated and acid leached, and beneficiated, acid leached and calcined samples are adequate for uses of the ceramic products because of containing fine particles.

Figure 2 shows the color changes of the kaolin before and after beneficiation; in the raw kaolin sample, a beige coloration is evident, the beneficiated and acid leached kaolin is essentially white, while imparts color to calcined kaolin (low brightness due to iron oxide impurity) and commercial kaolin (high brightness). The color of beneficiated and acid-leached kaolin is very close to the commercial kaolin. As additional data, figure 3 shows the images of the kaolin clay sample before and after beneficiation with a particle size of less than $45 \mu \mathrm{m}$ observed at an optical microscope (SMZ25). The observation with reflected light microscopy indicates that: the raw kaolin clay appears in different colors (show by the arrows): slightly white with a brownish red, yellow, and black color impurity due to iron oxide, titanoferrous, and pyrite (iron sulphide)/ilmenite, respectively, having the lowest whiteness index value of $72.0 \%$; the beneficiated and acid leached kaolin is essentially white, having the highest whiteness index value of $81.4 \%$. A similar observation was obtained by Scorzelli et al [59]. After the beneficiated, acid leached and calcined process, a yellow color pigment was appeared in the sample (see figure $3(\mathrm{c})$ ). This is due to the presence of iron-stained titania. Thus, the microscopic observation indicates that oxalic acid leaching has not completely removed the titanium dioxide $\left(\mathrm{TiO}_{2}\right)$ content. It was observed that $84.83 \%$ of iron impurities were removed from raw kaolin with an increase of whiteness index from 72 to $81.4 \%$. This reveals that the 
Table 2. Chemical composition in wt $\%$ of raw, beneficiated and acid leached, beneficiated, acid leached and calcined, and commercial kaolin.

\begin{tabular}{lcccc}
\hline Oxide & RK & BALK & BALCK & CK \\
\hline $\mathrm{SiO}_{2}$ & 59.20 & 60.10 & 60.30 & 59.10 \\
$\mathrm{Al}_{2} \mathrm{O}_{3}$ & 24.90 & 27.60 & 29.40 & 34.90 \\
$\mathrm{Fe}_{2} \mathrm{O}_{3}$ & 2.40 & 0.36 & 0.53 & 0.84 \\
$\mathrm{CaO}$ & 3.26 & 5.77 & 4.51 & - \\
$\mathrm{MgO}$ & 0.18 & - & 0.04 & 0.24 \\
$\mathrm{Na} 2 \mathrm{O}$ & 3.84 & 1.83 & 1.55 & - \\
$\mathrm{K}_{2} \mathrm{O}$ & 3.85 & 2.46 & 2.11 & 4.5 \\
$\mathrm{MnO}$ & 0.12 & - & 0.01 & - \\
$\mathrm{P}_{2} \mathrm{O}_{5}$ & 0.47 & - & 0.11 & 0.11 \\
$\mathrm{TiO}_{2}$ & 1.65 & 1.05 & 1.15 & - \\
$\mathrm{SiO}_{2} / \mathrm{Al}_{2} \mathrm{O}_{3}$ & 2.38 & 2.18 & 2.05 & 1.69 \\
$\mathrm{Al}_{2} \mathrm{O}_{3} / \mathrm{Fe}_{2} \mathrm{O}_{3}$ & 10.4 & 76.7 & 55.5 & 41.6 \\
$\mathrm{LOI}^{*}$ & 8.22 & 10.7 & 0.98 & 10.87 \\
& & & &
\end{tabular}

RK: Raw Kaolin; BALK: Beneficiated and Acid Leached Kaolin; BALCK: Beneficiated, Acid Leached, and Calcined Kaolin; CK: Commercial Kaolin; Loss on ignition (LOI ${ }^{*}$ ) at $1100^{\circ} \mathrm{C}$, for $1 \mathrm{~h}$.

beneficiated kaolin reaches an adequate whiteness index for the ceramics industry. According to the literature, the ceramic industry demands an ISO whiteness index above 80.0\% [19].

The surface area of separate kaolin samples was measured by the Brunauer-Emmett-Teller (BET) multipoint method. The measured specific surface area of kaolin ranges from 11.6 to $30.7 \mathrm{~m}^{2} \mathrm{~g}^{-1}$ for the various treatment. The lowest specific surface area $\left(11.6 \mathrm{~m}^{2} \mathrm{~g}^{-1}\right)$ was found for the raw kaolin clays while the highest specific surface area $\left(30.7 \mathrm{~m}^{2} \mathrm{~g}^{-1}\right)$ was obtained for the beneficiated and acid leached kaolin (see table 1). Similar results are reported in the literature $[15,60,61]$ for natural kaolinite clays. As can be seen in table 1 , the surface area is increased with oxalic acid treatment. It increases in the order of BALK $>$ BALCK $>$ CK $>$ RK. The increase in the surface area from raw kaolin clay to the beneficiated and acid-treated kaolin clay is due to the removal of the impurities within the pore kaolin mineral through the beneficiation process. However, the surface area of the beneficiated and acid leached kaolin clay treated at high temperature $\left(700^{\circ} \mathrm{C}\right)$ for $3 \mathrm{~h}$ is slightly decreasing to a value of $19.4 \mathrm{~m}^{2} \mathrm{~g}^{-1}$, whereas during calcination the pore volume and pore size increased due to losing their structure $[61,62]$.

\subsection{XRF characterization}

The chemical composition of raw, beneficiated, and acid leached, beneficiated and acid leached and calcined, and commercial kaolin as determined by WD-XRF is summarized in table 2 . The analysis result showed that the composition of $\mathrm{SiO}_{2}$ and $\mathrm{Al}_{2} \mathrm{O}_{3}$ varying between 59.20 and $60.30 \%$, and 24.90 and $34.90 \%$, respectively. On the other hand, the loss on ignition was varied between 8.22 and $10.87 \%$. These amounts were closest to the values determined for theoretical kaolin, indicating that after clay description and classification the kaolinite was enriched. In the present study, the samples treated with $2.0 \mathrm{M}$ oxalic acid were met the standard specification for the production of ceramics. The iron oxide $\left(\mathrm{Fe}_{2} \mathrm{O}_{3}\right)$ composition of the studied beneficiated and acid leached kaolin was compared to the standards set for ceramics [63] indicating the presence of small levels of iron oxides and hydroxides in the samples. The $\mathrm{SiO}_{2} / \mathrm{Al}_{2} \mathrm{O}_{3}$ and $\mathrm{Al}_{2} \mathrm{O}_{3} / \mathrm{Fe}_{2} \mathrm{O}_{3}$ mass ratios range from 2.05 to 2.38 and 10.4 to 76.7, respectively, for the different beneficiation steps. The lowest $\mathrm{SiO}_{2} / \mathrm{Al}_{2} \mathrm{O}_{3}$ values corresponding to the white kaolinite levels and the highest $\mathrm{Al}_{2} \mathrm{O}_{3} / \mathrm{Fe}_{2} \mathrm{O}_{3}$ values corresponding to alumina-rich, with a certain whitish color. From an industrial point of view, the $\mathrm{Al}_{2} \mathrm{O}_{3} / \mathrm{Fe}_{2} \mathrm{O}_{3}$ mass ratio could be used to define the possible end uses of the clays in the ceramic paste formulation [64]. Due to its lower iron oxide content and $\mathrm{SiO}_{2} / \mathrm{Al}_{2} \mathrm{O}_{3}$ mass ratio, and higher $\mathrm{Al}_{2} \mathrm{O}_{3} / \mathrm{Fe}_{2} \mathrm{O}_{3}$ mass ratio, beneficiated Debre Tabor kaolin is a suitable cheap raw material for developing ceramic membrane for water purification. Finally, the results show that the laboratory beneficiation improves the kaolin sample to a very high grade with a mineralogical, thermal, and physical properties and chemical composition close to that of commercial kaolin (see tables 1 and 2).

\subsubsection{XRD analysis}

The structural changes that appeared on the raw kaolin and beneficiated clay material were studied using the $\mathrm{x}$-ray diffraction technique. The raw, beneficiated, and acid leached, beneficiated, acid leached and calcinated and commercial kaolin clay shows well-defined diffractions at 2 theta value of $12.18-13.8^{\circ}, 23.55-24.9^{\circ}$, and $62.5^{\circ}$, these peaks are typically corresponding to kaolinite [32, 42]. On the other hand, the peaks corresponding 


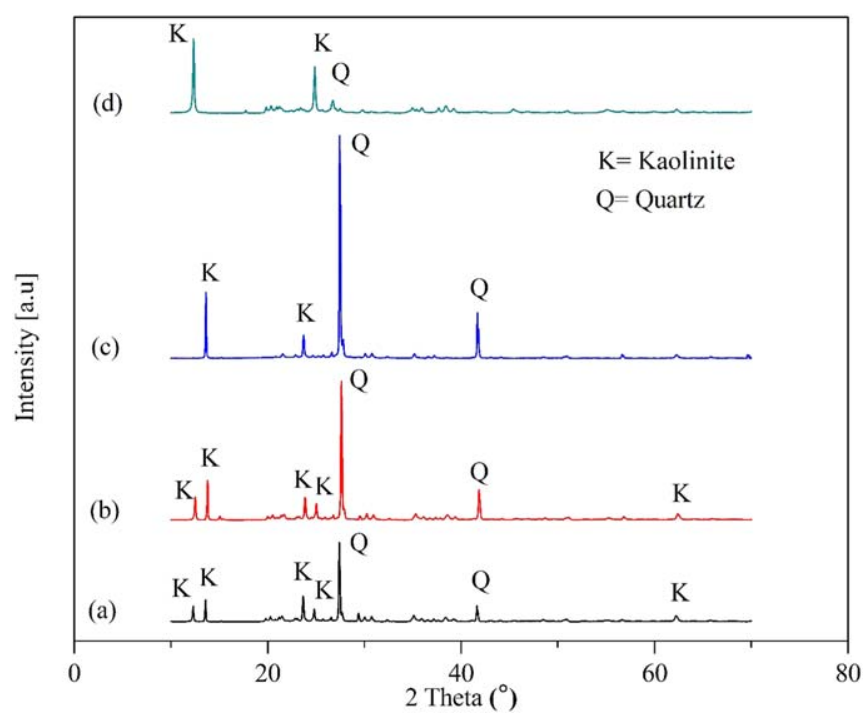

Figure 4. X-ray diffraction (XRD) patterns of (a) raw kaolin; (b) beneficiated and acid leached kaolin; (c) beneficiated, acid leached, and calcined kaolin; (d) commercial kaolin.

to the 2 Theta values $27.5^{\circ}$ and $41.6^{\circ}$, which are typical characteristics of quartz [65-67]. The obtained x-ray diffraction patterns indicated that the beneficiated, acid-leached, and calcinated material is rich in kaolinite and quartz. This is a confirmation that the quartz material was not completely removed through beneficiation, acid leaching, and calcination [67]. The presence of quartz in the mineralogical composition of the beneficiated, acidleached, and calcinated kaolin sample results in increasing the silicon dioxide $\left(\mathrm{SiO}_{2}\right)$ content [66]. This result supports the $\mathrm{x}$-ray fluorescence result presented in table 2 . A small peak corresponding to the 2 Theta values of $68.9^{\circ}$ for beneficiated, acid leached, and calcined kaolin figure 4(c), which is typically characteristic of titanium oxide ( $\mathrm{TiO} 2)$. This is a confirmation that the titanium oxide is released after calcination [32]. This result supports the optical microscope image of beneficiated, acid-leached, and calcined kaolin presented in figure $3(\mathrm{c})$.

\subsubsection{DSC/TGA analysis}

The thermal analyses (DSC/TGA) of the powdered raw, beneficiated and acid leached, beneficiated, acid leached and calcined, and commercial kaolin materials were performed using DSC/TGA, Model Q600 apparatus operating under a constant dry airflow at a heating rate of $10^{\circ} \mathrm{C} \mathrm{min}^{-1}$ between room temperature and $1100{ }^{\circ} \mathrm{C}$. Commercial kaolin was used as reference material for all experiments. The DSC/TGA profiles of the raw, beneficiated, and acid leached, beneficiated, acid leached and calcined, and commercial kaolin are shown in figures 5(a)-(d). The total weight loss of mass was $6.9 \mathrm{wt} \%$ for raw, $9.14 \mathrm{wt} \%$ for beneficiated and acid leached, $0.55 \mathrm{wt} \%$ for beneficiated, acid leached and calcined, and $9.14 \mathrm{wt} \%$ for commercial kaolin. TGA profile of the studied samples consists of two distinct stages. In the first stage of the endothermic reaction, the mass loss of raw, beneficiated and acid leached, beneficiated, acid leached and calcined, and commercial kaolin in the temperature range $30^{\circ} \mathrm{C}-140{ }^{\circ} \mathrm{C}$ was $0.3 \mathrm{wt} \%, 1.25 \mathrm{wt} \%, 0.099 \mathrm{wt} \%$, and $0.16 \mathrm{wt} \%$, respectively which is attributed to the loss of surface, adsorbed/interlayer, and void water $[64,68,69]$. From $140{ }^{\circ} \mathrm{C}$ to $360^{\circ} \mathrm{C}$, a net weight gain of $0.062 \mathrm{wt} \%$ and $0.34 \mathrm{wt} \%$ was recorded for beneficiated, acid leached, and calcined kaolin, and commercial kaolin, respectively, which is attributed to oxygen chemisorption occurring prior to the onset of combustion (figures 5(b), (d)).

In the second stage of the endothermic reaction, several mass losses were observed in the temperature range of $400{ }^{\circ} \mathrm{C}-800^{\circ} \mathrm{C}$ due to the loss of hydroxyl groups (dehydroxylation of the kaolinite) from the kaolin structure $[44,64,68-71]$. In this stage, phase transformation chemical reaction occurred kaolin $\left(\mathrm{Al}_{2} \mathrm{Si}_{2} \mathrm{O}_{5}(\mathrm{OH})_{4}\right)$ to metakaolin $\left(\mathrm{Al}_{2} \mathrm{Si}_{2} \mathrm{O}_{7}\right)$ and showed a significant mass loss of up to $6.09 \mathrm{wt} \%$ of the raw, $7.2 \mathrm{wt} \%$ of the beneficiated and acid leached, and $0.38 \mathrm{wt} \%$ of beneficiated, acid leached and calcined, and $8.9 \mathrm{wt} \%$ of the commercial kaolin. This major mass loss and intense endothermicity are because of the combustion of organic matter and carbon. The conversion of kaolin to metakaolin is further supported by the results from the XRD analysis by the disappearance of kaolinite peaks.

It can be determined in DSC curves that exothermic peaks appeared for all the kaolin powder samples. The exothermic peak occurs at a temperature between $50{ }^{\circ} \mathrm{C}$ to $60^{\circ} \mathrm{C}$ for all indicated the removal of the free water molecules present in the kaolin mineral. The endothermic peak experienced at $140{ }^{\circ} \mathrm{C}$ for beneficiated and acid 


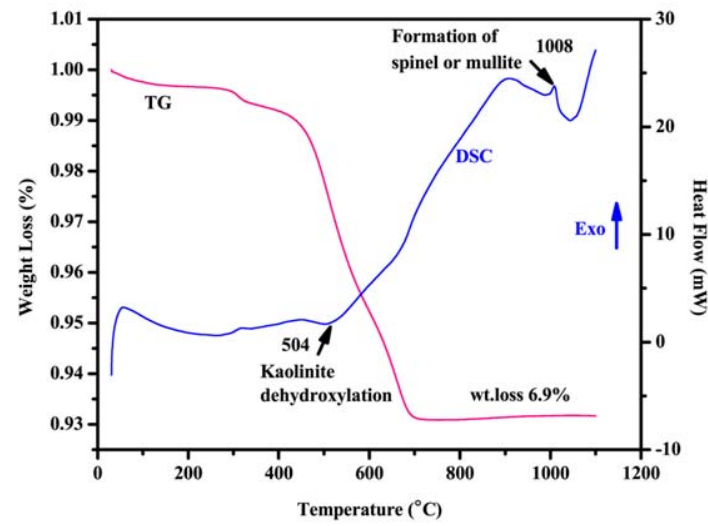

(a)

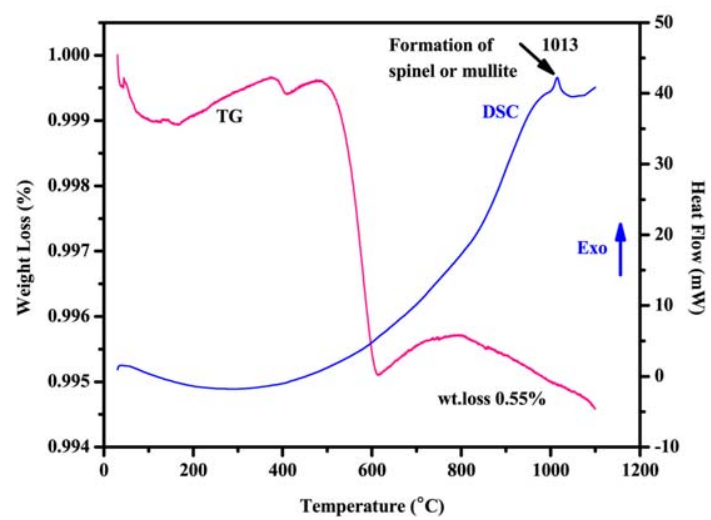

(c)

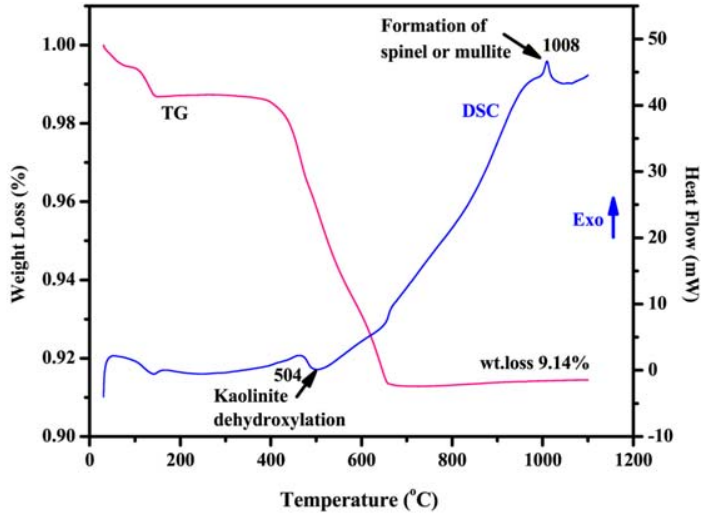

(b)

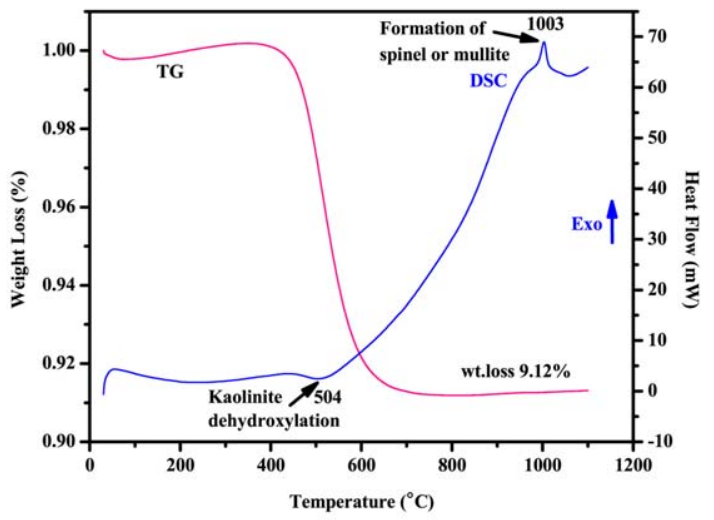

(d)

Figure 5. TGA/DSC diagrams of (a) raw kaolin; (b) beneficiated and acid leached kaolin; (c) beneficiated, acid leached, and calcinated kaolin; (d) commercial kaolin.

leached kaolin was corresponding to hygroscopic water loss (figure 5(b)). The endothermic peak experienced at $504^{\circ} \mathrm{C}$ for raw, beneficiated and acid leached, and commercial kaolin was corresponding to organic matter decomposition and the transformation of kaolin to metakaolin caused by the dehydroxylation of a coordinated and structural water molecule $[61,71]$. The absence of any major endothermic peak at $504{ }^{\circ} \mathrm{C}$ for beneficiated, acid leached, and calcinated kaolin confirmed that almost complete removal of structural water could be achieved in beneficiated, acid leached, and calcinated kaolin sample (figure 5(c)). All samples exhibit an exothermic peak at $1003^{\circ} \mathrm{C}-1013^{\circ} \mathrm{C}$ in the DSC pattern due to an amorphous transformation and formation of spinel and/ or mullite in the minerals (figures 5(a)-(d)). This transformation doesn't engage in any mass loss. Similar results were obtained in their studies with kaolin $[61,68,69,71]$.

\subsubsection{FTIR analysis}

FTIR was used to identify the crystal structures, functional groups existing in the samples, and other structural defects. FTIR spectra of the raw, beneficiated and acid leached, beneficiated, acid leached and calcined, and commercial kaolin are illustrated in figures 6(a)-(d). The peaks of the raw, beneficiated, and acid leached, and commercial kaolin clearly shows a sharpness at those bands but the beneficiated, acid leached and calcined kaolin exhibit an insignificant peak. Bands at 763 and 690 were related to the perpendicular vibrations of Si-OH [72]. A band at $910 \mathrm{~cm}^{-1}$ was attributed to $\mathrm{OH}$ deformation linked to iron cation $\left(\mathrm{Fe}^{3+}\right)$ and aluminum cation $\left(\mathrm{Al}^{3+}\right)[60]$.

Bands at $1114 \mathrm{~cm}^{-1}$ and $1018 \mathrm{~cm}^{-1}$ were attributed to the stretching vibration of $\mathrm{Si}-\mathrm{O}$ and/or $\mathrm{Al}-\mathrm{O}$ and the symmetric stretching vibrations of $\mathrm{Si}-\mathrm{O}-\mathrm{Si}$ bonds. This confirms that the studied kaolin contained a high proportion of silicon oxide. The spectra of the beneficiated and acid leached kaolin (figure 6(b)) show the new small intensity peaks at $1634 \mathrm{~cm}^{-1}$, comparing to the spectrum of the raw, beneficiated, acid leached and calcined, and commercial kaolin which could be described as $\mathrm{H}-\mathrm{O}-\mathrm{H}$ bending modes of water [73]. Bands at $3620 \mathrm{~cm}^{-1}$ and $3693 \mathrm{~cm}^{-1}$ in raw, beneficiated, and acid leached, and commercial kaolin was assigned to the $\mathrm{OH}$ stretching of water [74]. Beneficiated, acid leached and calcined do not contain $\mathrm{OH}^{-}$and $\mathrm{Al}-\mathrm{O}$ because of the loss of the structural hydroxyl group due to the calcination process (calcination leads to the dehydroxylation at temperatures in the range of $400^{\circ} \mathrm{C}-800{ }^{\circ} \mathrm{C}$ ), while $\mathrm{Si}-\mathrm{O}$ bands appeared during the calcination process 


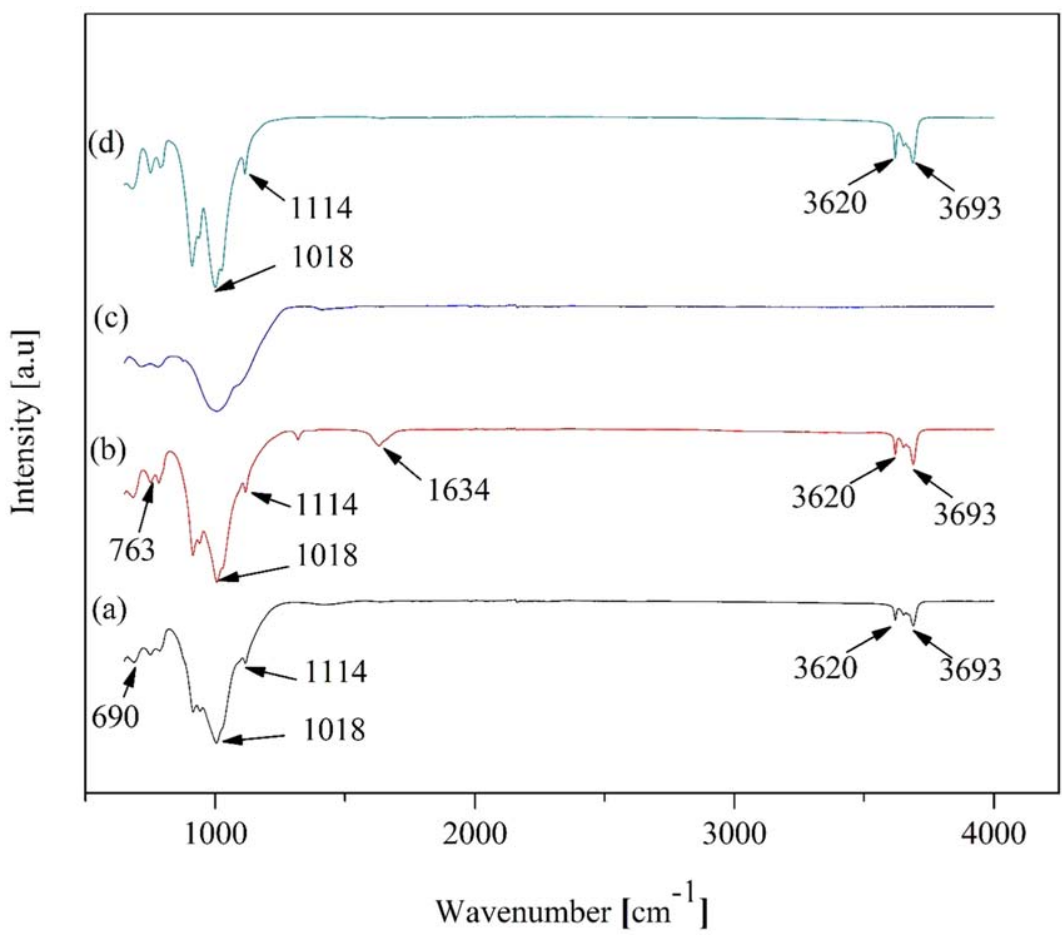

Figure 6. FTIR spectra of the samples (a) raw kaolin; (b) beneficiated and acid leached kaolin; (c) beneficiated, acid leached and calcined kaolin; (d) commercial kaolin

(figure 6(c)). The FTIR result shows that thermal treatment was adequate to convert kaolin to metakaolin. The formation of metakaolin can be inferred by the disappearance of multiple bands in the FTIR spectrum of kaolin in the wavenumber range of $3600-3700 \mathrm{~cm}^{-} 1$. Beneficiated, acid-leached and calcined kaolin has enhanced percent transmittance than the raw and commercial kaolin.

\subsubsection{SEM observations}

The scanning electron micrographs of the different kaolin samples are presented in figures 7(a)-(d). The SEM image (figure 7(a)) reveals the presence of large particles that appeared to have been formed by several flaky particles stacked together to form a compact arrangement in hexagonal shapes, irregular bulk edges, and surfaces, and flattened platelets structure of kaolinite [3, 18, 21, 32, 34, 75]. In comparison to the commercial kaolin clay (figure 7(d)), the beneficiated and acid leached product (figure 7(b)) was similar morphological features. After oxalic acid leaching and calcination figure 7(c), the platelet structure/larger particles of the kaolin were broken down, disaggregated, and produced a more porous structure which caused an increase in surface area (table 1). Moreover, due to the removal of the impurities from raw kaolin, more distribution, fragmentation, and fewer aggregations occurred during beneficiation. This results in the formation of a more porous structure. it is also evident that the surface of beneficiated, acid-leached, and calcinated kaolin has homogenous and clear particles with a small flake shape. A similar observation was reported in the literature $[18,32,34,61,75,76]$ for kaolinite minerals.

\subsection{Leaching studies}

\subsubsection{Effect of contact time and acid concentration}

The effect of oxalic acid concentrations $(0.1 \mathrm{M}$ to $2.0 \mathrm{M})$ at different leaching times on iron removal from the hydrous kaolin is shown in figure 8 . The dissolution curves appear to be parabolic as oxalic acid concentration increases from $0.5 \mathrm{M}$ to $2.0 \mathrm{M}$. It can also be observed that iron dissolution was very slow at an oxalic acid concentration of $0.1 \mathrm{M}$. The maximum removal of iron at different concentrations of oxalic acid, i.e., $0.1 \mathrm{M}$, $0.5 \mathrm{M}, 1 \mathrm{M}, 1.5 \mathrm{M}$, and $2 \mathrm{M}$ at $120^{\circ} \mathrm{C}$ for $120 \mathrm{~min}$ was $27.68 \pm 0.74,77.65 \pm 0.5,73.49 \pm 0.2,83.02 \pm 0.1$ and $84.83 \pm 0.24 \%$, respectively. As summarized in figure 8 , the minimum and maximum iron ore dissolution are $19.97 \pm 0.4 \%$ and $84.83 \pm 0.24 \%$ at a contact time of $120 \mathrm{~min}$, leaching temperature of $120^{\circ} \mathrm{C}$ for an oxalic acid concentration of $0.1 \mathrm{M}$ and $2.0 \mathrm{M}$, respectively. Thus, $2.0 \mathrm{M}$ oxalic acid was to be the maximum concentration for leaching of iron from hydrous kaolin. This suggests that the oxides, hydroxides, and hydrated oxides of total iron impurities associated with kaolin clay are easily solubilized in oxalic acid. According to the results of the present study, it can be concluded that the removal of iron increased by increasing the reaction time and oxalic 


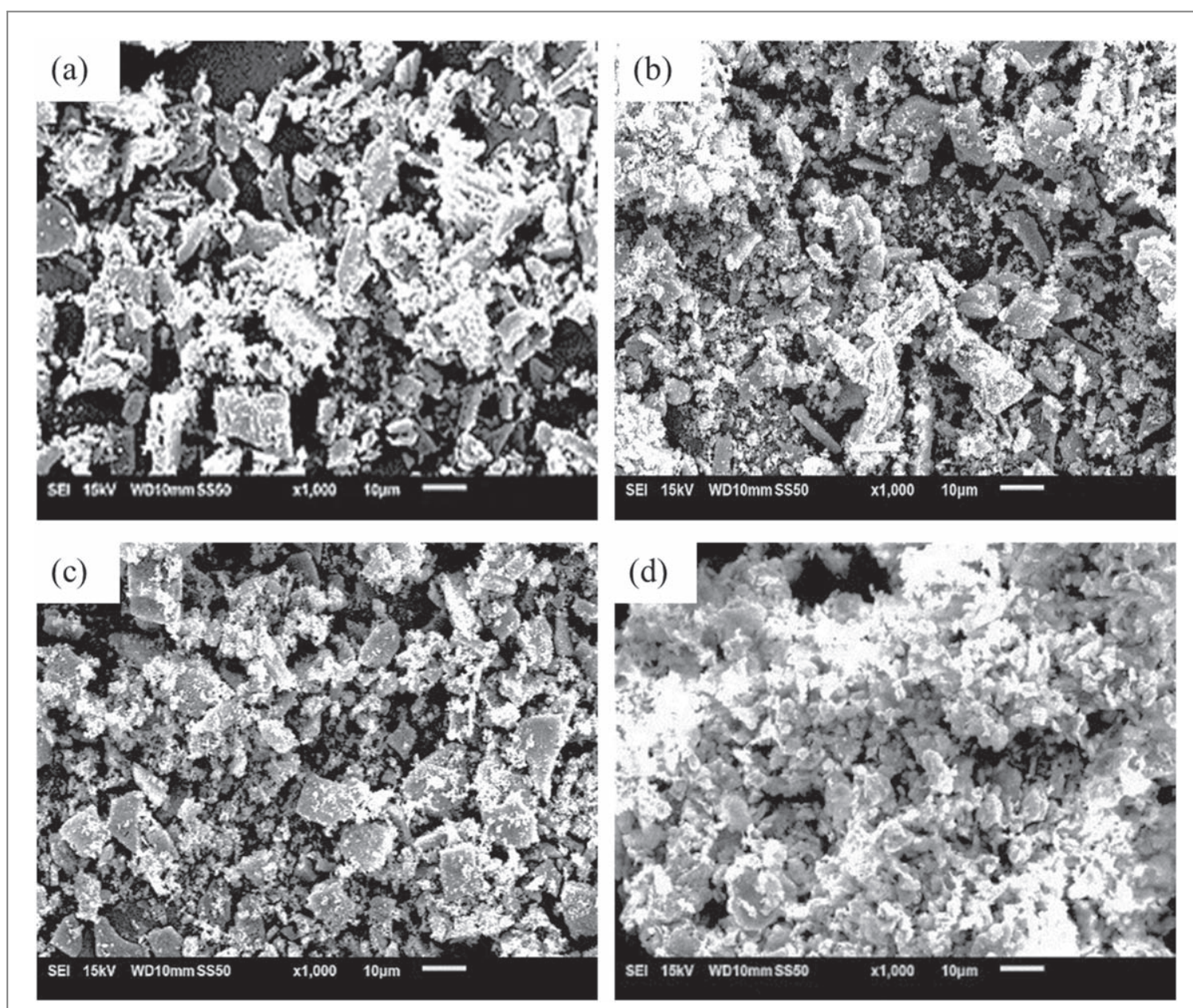

Figure 7. SEM observations of (a) raw kaolin; (b) beneficiated and acid leached kaolin; (c) beneficiated, acid leached and calcined kaolin; (d) commercial kaolin.

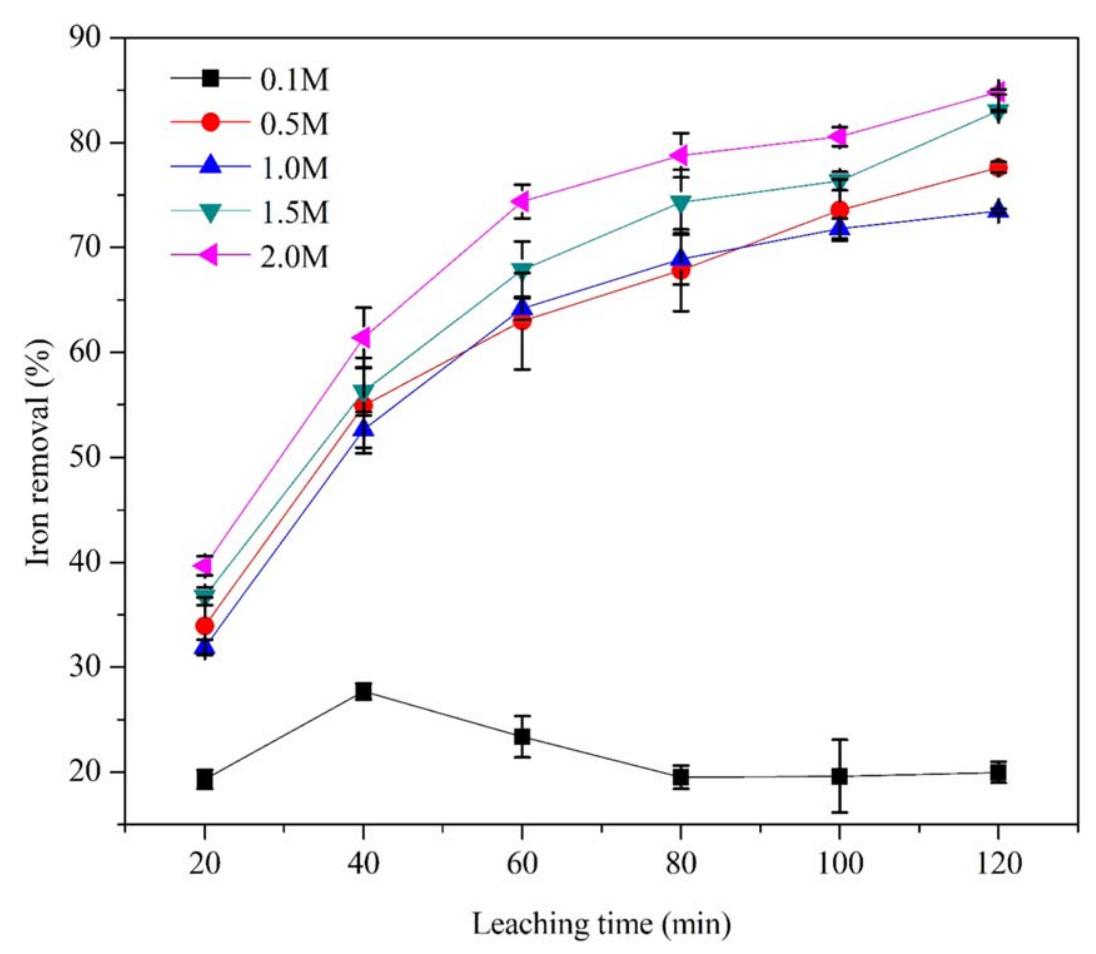

Figure 8. Effect of leaching time and acid concentration on the extraction of iron from raw kaolin $\left(120^{\circ} \mathrm{C}\right.$, less than $\left.45 \mu \mathrm{m}\right)$. 


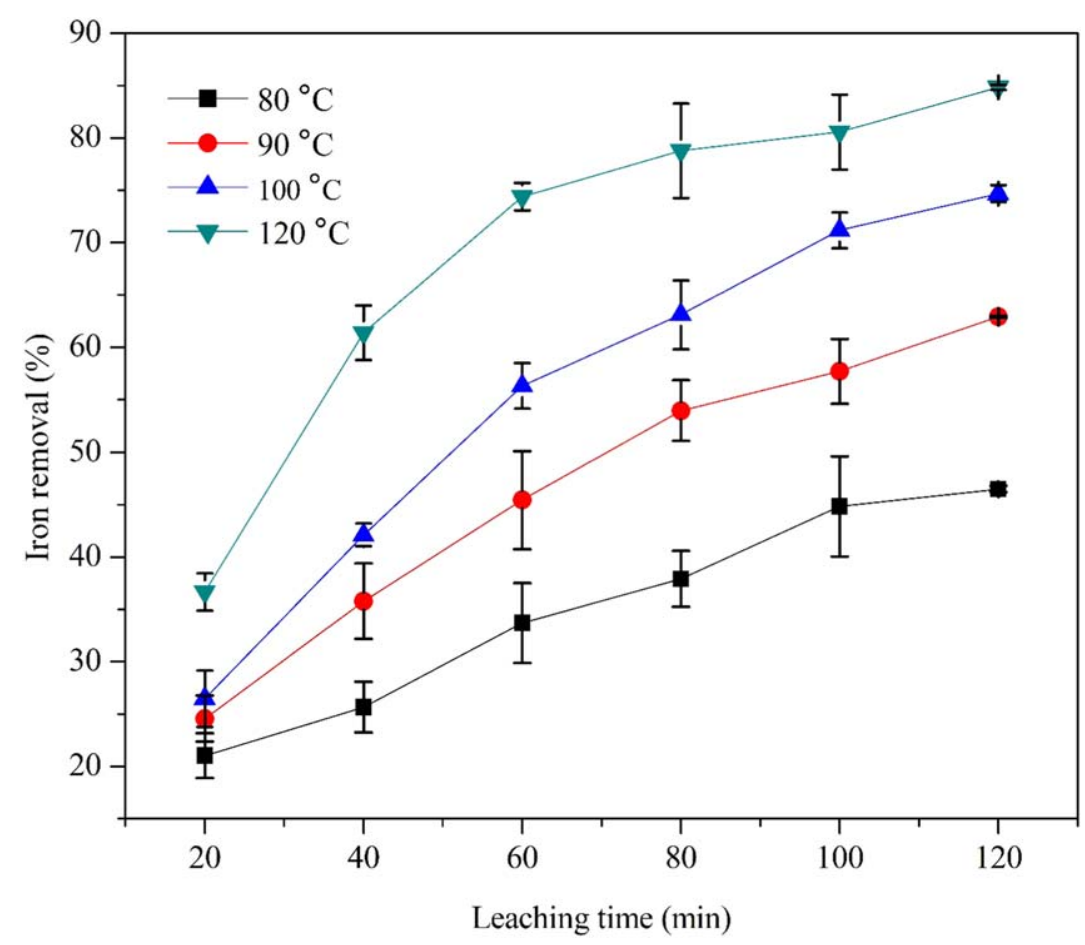

Figure 9. Effect of leaching time and temperature on the extraction of iron from raw kaolin $\left(80^{\circ} \mathrm{C}-120^{\circ} \mathrm{C}\right)(2.0 \mathrm{M}$ oxalic acid, less than $45 \mu \mathrm{m})$.

acid concentration, indicating that both parameters play a major role in the dissolution of iron. Several studies also observed a similar trend during the removal of iron from kaolin clay [11], and other clay materials $[23,77,78]$.

\subsubsection{Effect of contact time and temperature}

From figure 9, it can be observed that the removal of iron increased with leaching temperature and reaction time, indicating that both parameters play a major role in the extraction of iron. As can be seen in the figure, the maximum removal efficiency of iron is found to be $46.47 \pm 0.31 \%, 62.91 \pm 0.1 \%, 74.69 \pm 0.8 \%$, and $84.83 \pm$ $0.24 \%$ at a temperature of $80,90,100$, and $120^{\circ} \mathrm{C}$, respectively. This shows a marginal increase in the amount of the hydrous kaolin reacted with leaching time within the studied temperature ranges $\left(80^{\circ} \mathrm{C}-120^{\circ} \mathrm{C}\right)$. It is also indicated that iron dissolution using oxalic acid could be thermally activated to improve its removal efficiency. Therefore, a higher leaching temperature and longer time enhance iron dissolution due to the enhancement in diffusion rate or chemical reaction. Several studies also observed a similar trend during the removal of iron from kaolin clay [11, 43], and other clay materials [23, 77, 78].

\subsection{Characterization of the membranes}

In general, these Ethiopian kaolin deposits, after their beneficiation, acid leaching, and calcination, are able to give kaolin clay of the required properties for the commercial market. The mineralogy, chemical analysis, and physical properties of final beneficiated Ethiopian kaolin clay successfully match the required specifications for many industrial processes. The suitability of raw clay for its use in the manufacture of ceramic products is determined by the mineralogy, chemistry, and physical properties of the material. This work has demonstrated that the beneficiated Ethiopian kaolin clay is a suitable cheap raw material for developing ceramic membrane for water purification and this shows that the beneficiation techniques (physical, chemical, and thermal) applied in the study are worthy following.

Clays with a chemical composition of $5 \%$ or more of $\mathrm{Fe}_{2} \mathrm{O}_{3}$ are used as red-firing clays, those with between 1 and $5 \%$ are buff-burning clay and those containing less than $1 \%$ are white burning clays [79-82]. Therefore, it was concluded from the chemical composition of the studied samples, due to the low amount of iron oxide (less than 1\%) in the clays (table 2), beneficiated and acid-leached kaolin clays could be used for ceramic membrane production. Moreover, in order to evaluate the suitability of the studied kaolin for ceramic products, the mass loss, linear shrinkage, water absorption, porosity, wettability property, chemical stability, and surface morphology of the flat ceramic bodies were studied at different firing temperatures $\left(500^{\circ} \mathrm{C}-1100{ }^{\circ} \mathrm{C}\right.$ for $\left.1 \mathrm{~h}\right)$. 

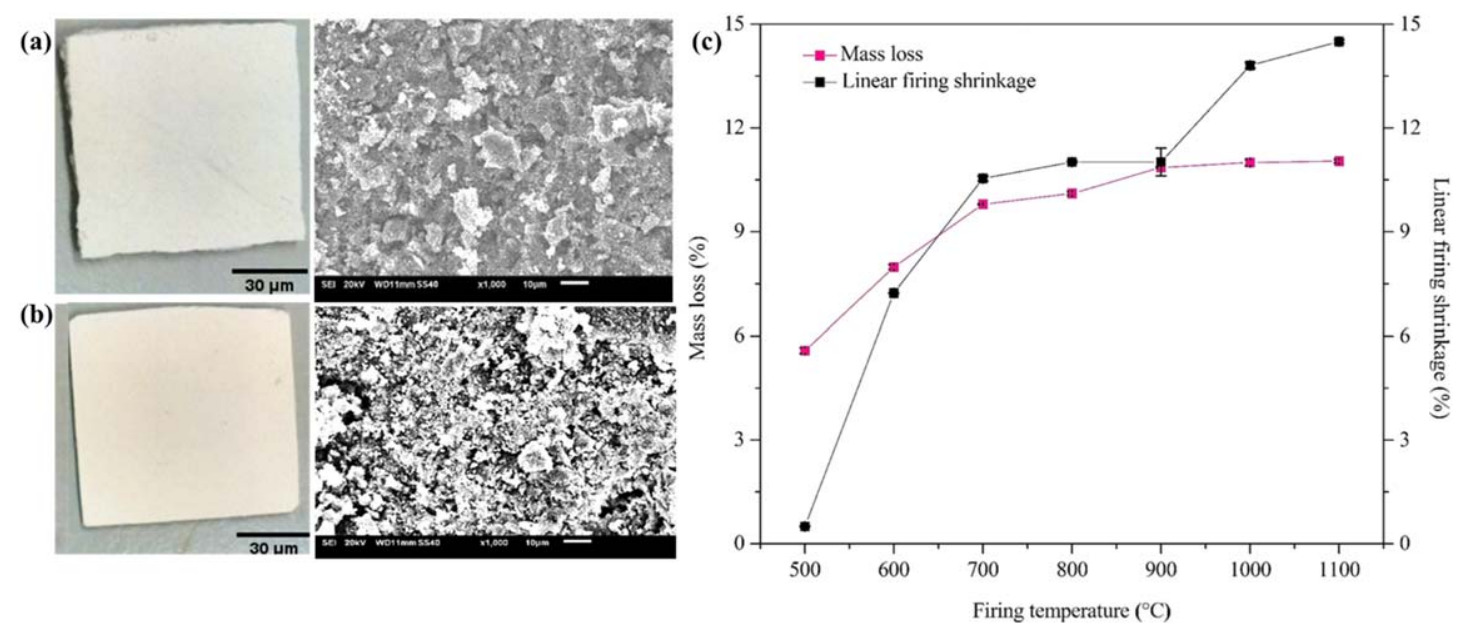

Figure 10. Optical microscope and SEM images of ceramic bodies sintered at (a) $500{ }^{\circ} \mathrm{C}$; (b) $1100{ }^{\circ} \mathrm{C}$, and (c) The mass loss and linear firing shrinkage of flat ceramic bodies sintered at different firing temperatures $\left(500{ }^{\circ} \mathrm{C}-1100^{\circ} \mathrm{C}\right)$ for $1 \mathrm{~h}$.

Figure 10 displays the optical microscope and SEM image of ceramic bodies sintered at $500{ }^{\circ} \mathrm{C}$ and $1100{ }^{\circ} \mathrm{C}$ and mass loss and linear firing shrinkage of fired flat ceramic samples at different firing temperatures $\left(500^{\circ} \mathrm{C}-\right.$ $1100^{\circ} \mathrm{C}$ ). The mass loss of the flat ceramic specimen fired at $500^{\circ} \mathrm{C}$ was found to be $5.58 \pm 0.08$. On further increase of the final firing temperature to $600{ }^{\circ} \mathrm{C}, 700{ }^{\circ} \mathrm{C}, 800{ }^{\circ} \mathrm{C}, 900{ }^{\circ} \mathrm{C}, 1000^{\circ} \mathrm{C}$ a mass loss of $7.98 \pm 0.07 \%$, $9.80 \pm 0.01 \%, 10.11 \pm 0.05 \%, 10.86 \pm 0.02 \%$, and $11.00 \pm 0.09 \%$, respectively was observed. Finally, the maximum mass loss for the flat ceramic specimen fired at $1100{ }^{\circ} \mathrm{C}$ was observed to be $11.04 \pm 0.05 \%$ (figure 10(c)), which is in good agreement with the loss on ignition (table 2) and thermogravimetry analysis (figure 5). The values of mass loss were increased linearly from $500{ }^{\circ} \mathrm{C}-900{ }^{\circ} \mathrm{C}$ and then increase marginally with increasing temperature to a maximum mass loss of $11.00 \pm 0.09 \%$. Similar observations were reported in the literature [37].

Similarly, the linear shrinkage of samples continuously increased with an increase in temperature (figure 10(c)). The flat ceramic specimen was found to shrink with a change volume of $0.5 \pm 0.02 \%$ and $7.23 \pm$ $0.01 \%$ when fired to final temperatures of $500{ }^{\circ} \mathrm{C}$ and $600{ }^{\circ} \mathrm{C}$, respectively. The shrinkage between $500{ }^{\circ} \mathrm{C}$ and $600^{\circ} \mathrm{C}$ was a consequence of the combustion of organic matter. On further increase of final firing temperatures of $700{ }^{\circ} \mathrm{C}, 800{ }^{\circ} \mathrm{C}, 900{ }^{\circ} \mathrm{C}, 1000^{\circ} \mathrm{C}$ a shrinkage increase was observed to values of $10.54 \pm 0.07 \%, 11.02 \pm 0.03 \%$, $11.02 \pm 0.4 \%$, and $13.81 \pm 0.08 \%$, respectively. Finally, the maximum shrinkage of volume for the flat ceramic specimen fired at $1100{ }^{\circ} \mathrm{C}$ was observed to a value of $14.5 \pm 0.05 \%$. The shrinkage of the flat sheet membrane is further incremented as the temperature increased. The increment in the shrinkage is due to the formation of a sintering neck caused by the diffusion of the particles in the flat sheet membrane. This was confirmed by the formation of the mullite phase; this was also reported in the literature for kaolin and other clay materials [81, 83-87]. From optical images, it can be seen that the flat sheet ceramic membrane has shrunk when the sintering temperature increased from $500^{\circ} \mathrm{C}$ to $1100^{\circ} \mathrm{C}$. Moreover, the SEM images indicated that the surface morphology changed with changing sintering temperature from $500^{\circ} \mathrm{C}$ to $1100{ }^{\circ} \mathrm{C}$ (figures 10 (a)-(b)).

Figure 11 displays the water absorption and porosity of fired flat ceramic samples at different firing temperatures. Water absorption of a flat ceramic specimen is $21.3 \pm 0.06 \%$ after firing at a temperature of $500{ }^{\circ} \mathrm{C}$ and is decreased up to $19.2 \pm 0.12,18.4 \pm 0.3,17.08 \pm 0.26,16.47 \pm 0.08,14.5 \pm 0.01$, and $8.9 \pm 0.4 \%$ after firing at a temperature of $600{ }^{\circ} \mathrm{C}, 700{ }^{\circ} \mathrm{C}, 800^{\circ} \mathrm{C}, 900{ }^{\circ} \mathrm{C}, 1000^{\circ} \mathrm{C}$, and $1100{ }^{\circ} \mathrm{C}$, respectively. It can be stated that water absorption values tended to decrease with an increase of firing temperature due to the particles close together and reduce porosity during the firing process. A similar trend was reported in the literature for the kaolin-based ceramic body [44], and other types of the clay-based ceramic body [81, 85].

As can be depicted in figure 11, two stages are observed for the porosity profile. In the first stage, the porosity of the flat ceramic specimen increases from $29.24 \pm 0.04 \%$ to $36.54 \pm 0.9 \%$ when the firing temperature is increased from $500{ }^{\circ} \mathrm{C}$ to $700{ }^{\circ} \mathrm{C}$ while it decreases to $25.08 \pm 0.55,22.26 \pm 0.3,19.63 \pm 0.89$, and $14.96 \pm 0.62 \%$ keeping the temperature to $800^{\circ} \mathrm{C}, 900^{\circ} \mathrm{C}, 1000^{\circ} \mathrm{C}$, and $1100^{\circ} \mathrm{C}$, respectively. A similar trend was observed in the literature for kaolinite clay minerals [37]. The first stage of the curve (increased pattern) indicates an opening of the macropores and mesopores with temperature, whereas the second stage of the curve (decreased pattern) is caused by the fusing of the grains under the effect of heat and the particles tend to agglomerate with each other that enhance the densification of the flat ceramic bodies [38, 88]. An increase in final firing temperature leads to a decrease in the porosity of the flat ceramic bodies down to a value of $14.96 \pm 0.62 \%$. A similar trend was reported 


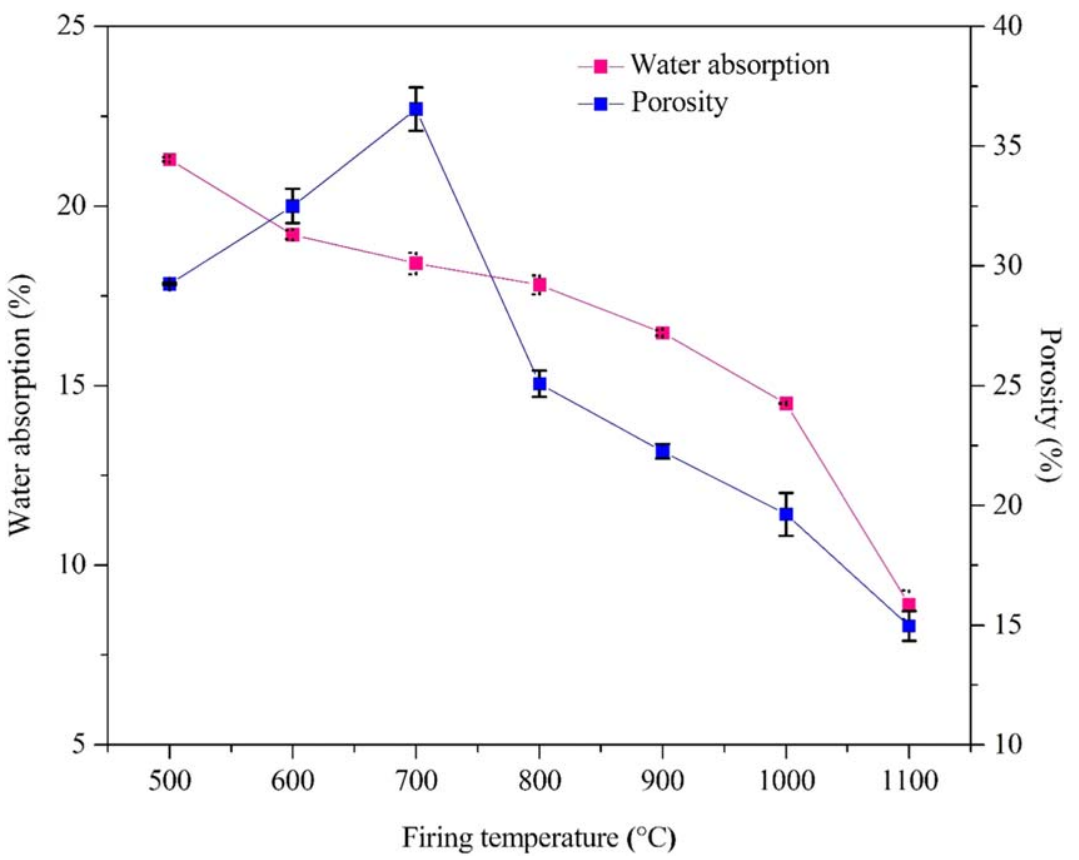

Figure 11. Variation of water absorption and porosity of flat ceramic specimens produced from beneficiated and acid leached kaolin at various final calcination temperatures $\left(500^{\circ} \mathrm{C}-1100^{\circ} \mathrm{C}\right.$ for $\left.1 \mathrm{~h}\right)$.

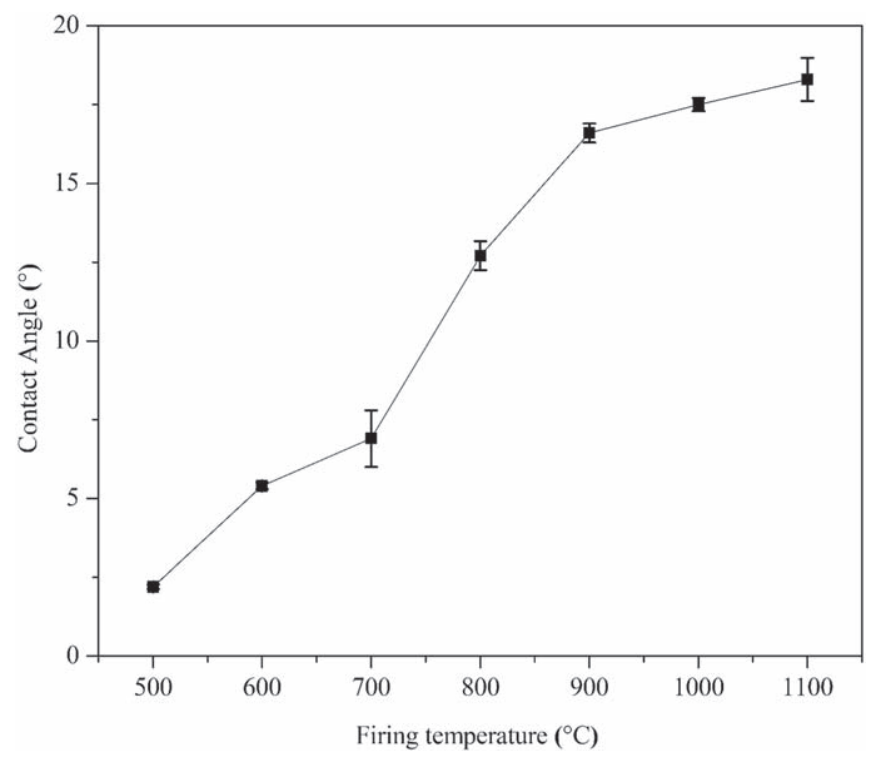

Figure 12. Wetting angle measurements of flat ceramic specimens produced from beneficiated Debre tabor kaolin at various final calcination temperatures $\left(500^{\circ} \mathrm{C}-1100^{\circ} \mathrm{C}\right.$ for $\left.1 \mathrm{~h}\right)$.

in the literature for kaolin based ceramic specimens [1, 41, 44, 71, 83, 86, 89-94] and other types of clay-based ceramic specimens $[37,85,95,96]$. Finally, the porosity of a flat ceramic specimen is directly related to water absorption, both properties show a similar trend in the firing temperature range $700{ }^{\circ} \mathrm{C}-1100{ }^{\circ} \mathrm{C}$.

Figure 12 illustrates the wettability properties of the fired flat ceramic specimen at different temperatures. The results show that all the contact angles of the flat ceramic specimens are lower than $90^{\circ}$. This is a characteristic of hydrophilic surfaces that are capable to absorb water. The contact angle values of the flat ceramic specimens fired at $500^{\circ} \mathrm{C}$ and $600{ }^{\circ} \mathrm{C}$ were $2.2^{\circ} \pm 0.07$ and $5.4^{\circ} \pm 0.1$, respectively, which indicates superhydrophilic behavior. An increase in firing temperature leads to an increase in the contact angle of the flat ceramic specimens up to values of $18.3^{\circ} \pm 0.68$ with a firing temperature of $1100^{\circ} \mathrm{C}$ and still in the range of hydrophilicity behavior. Similar observations were reported in literature [53, 94]. 


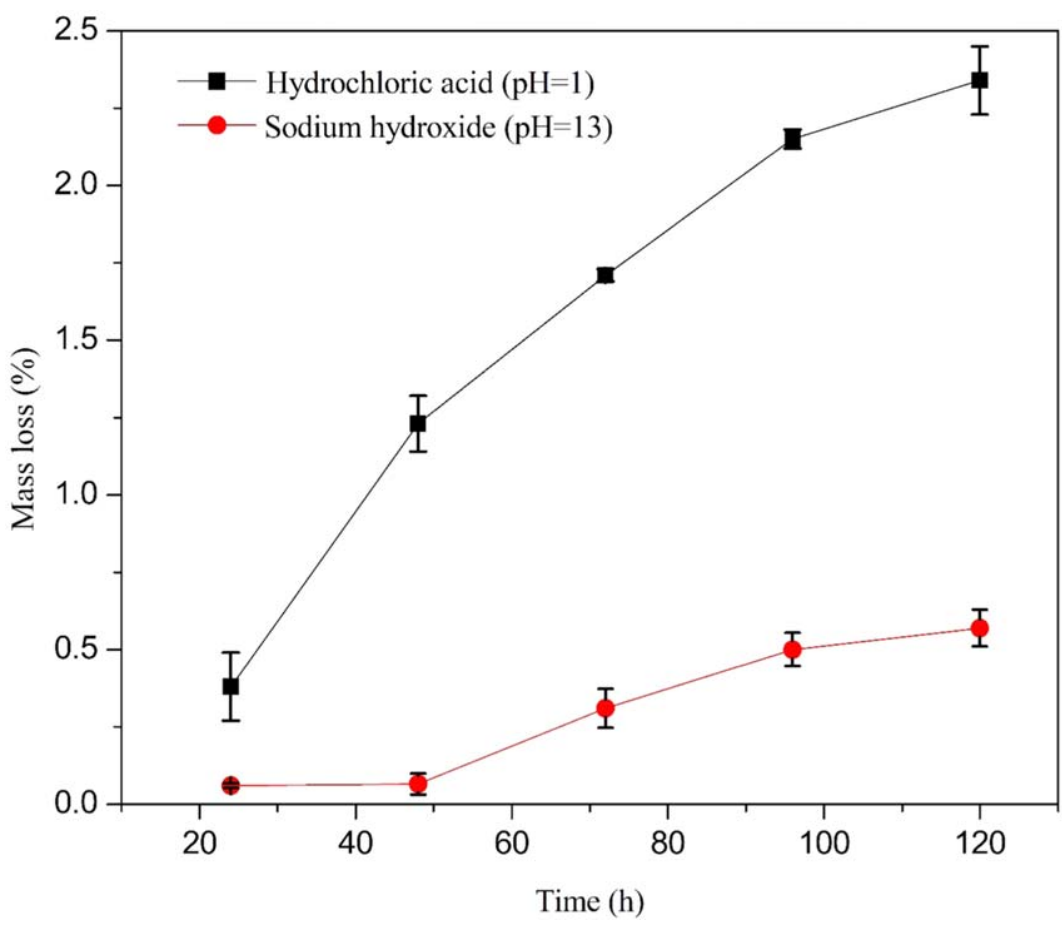

Figure 13. Mass loss of flat kaolin-based ceramic membrane (sintered at $1100^{\circ} \mathrm{C}$ for $1 \mathrm{~h}$ ) versus exposure time in acid solution $(\mathrm{HCl}$, $\mathrm{pH}=1)$ and alkaline $(\mathrm{NaOH}, \mathrm{pH}=13)$ solution.

The chemical stability was estimated in terms of weight loss after immersing the flat ceramic specimen in acid and alkali solution. A small part of the ceramic membrane was kept in acidic conditions in contact with $\mathrm{HCl}$ solution $(\mathrm{pH}=1)$ and alkali conditions in contact with $\mathrm{NaOH}$ solution $(\mathrm{pH}=13)$ separately for $24,48,72,96$, and $120 \mathrm{~h}$ at atmospheric conditions. Then the flat ceramic specimens were taken out from the solution, washed with distilled water, and dried at $110^{\circ} \mathrm{C}$ for $24 \mathrm{~h}$. The weight loss in acid solution was recorded to be $0.38 \pm 0.11$, $1.23 \pm 0.09,1.71 \pm 0.02,2.15 \pm 0.03$, and $2.34 \pm 0.11 \%$ for $24,48,72,96$, and $120 \mathrm{~h}$ contact time, respectively. Whereas, the weight loss in alkali solution was found to be $0.060 \pm 0.008,0.066 \pm 0.034,0.31 \pm 0.063,0.5 \pm$ 0.054 , and $0.57 \pm 0.06 \%$ for $24,48,72,96$, and $120 \mathrm{~h}$ contact time, respectively. The obtained results reveal that the flat ceramic specimens with the acid solution were observed to lose more weight than flat ceramic specimens with an alkali solution (figure 13). On the other hand, as immersion time increases, the mass loss of the flat ceramic membrane also slightly increased in both acid and alkali conditions. Nevertheless, the prepared flat ceramic specimen offers good chemical stability in acidic ( $<3 \%$ mass loss in acid solution) and excellent chemical stability in basic media ( $<1 \%$ mass loss in alkali solution). The obtained results are comparable with kaolin based ceramic bodies [71, 83, 89,91,97] and other types of clay-based ceramic bodies $[37,83,95,96,98,99]$.

Scanning electron microscopy (SEM) micrographs reported in figures 14(a)-(g) show the surface of flat ceramic membrane sintered at different temperatures and give information on the surface morphology of the membrane as a function of the temperature treatment $\left(500^{\circ} \mathrm{C}, 600^{\circ} \mathrm{C}, 700^{\circ} \mathrm{C}, 800^{\circ} \mathrm{C}, 900{ }^{\circ} \mathrm{C}, 1000^{\circ} \mathrm{C}\right.$, and $1110^{\circ} \mathrm{C}$ ). SEM micrographs indicate that the effect of sintering temperature on the microstructure of the kaolinbased ceramic membrane is remarkable; a progressive reduction of porosity or a typical sequence of enhancing densification can be observed when the sintering temperature increases from $500^{\circ} \mathrm{C}$ to $1100^{\circ} \mathrm{C}$ $[41,83,86,91,99]$. The flat ceramic membrane sintered at $1100^{\circ} \mathrm{C}$ with a porosity of $14.96 \pm 0.62 \%$, consisted of non-uniform grain size and strongly interconnected (the particles agglomerate together creating more dense structure), and formation of large pores (larger diameter) (figure 14(g)), whereas the flat ceramic membrane sintered at $500{ }^{\circ} \mathrm{C}$ and with a porosity of $29.24 \pm 0.04 \%$, consisted of loosely interconnected kaolin grains (open pore structure), poor consolidated and small pores (figure 14(a)). A further increase in temperature to $700^{\circ} \mathrm{C}$ causes a visible change in the surface morphology with a porosity of $36.54 \pm 0.9 \%$ show a highly porous structure (figure 14(c)). Moreover, it was visible that the pore size and pore structure changed with an increase in the sintering temperature $[1,41,83,91,93,99]$. It is to be noted that the degree of bonding between the kaolin particles became stronger with an increase in the temperature. Since the higher sintering temperature gives more consolidation and densification, and formation of voids and large pores for the kaolin-based ceramic membrane. The observations of the SEM indicate that the membrane did not contain any damages, e.g., cracks. 


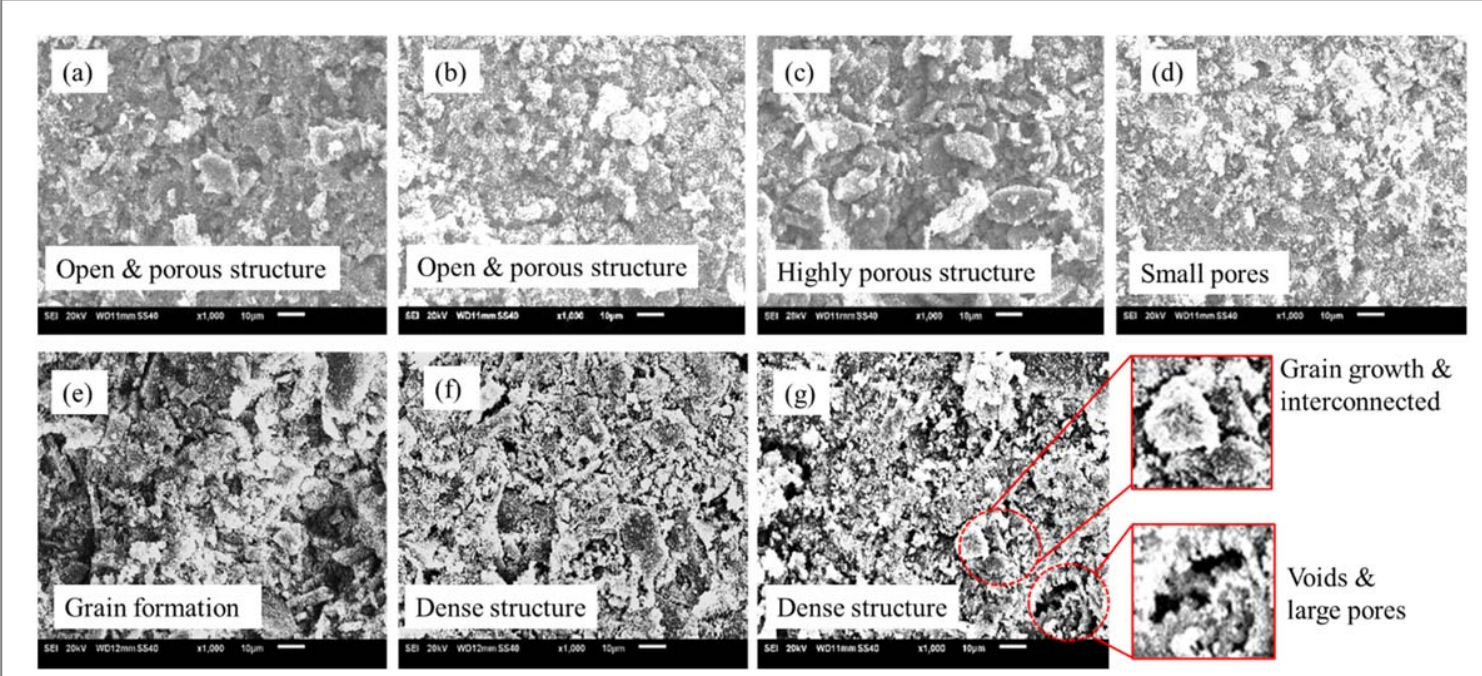

Figure 14. SEM micrographs of the flat kaolin-based ceramic membrane sintered at: (a) $500{ }^{\circ} \mathrm{C}$; (b) $600{ }^{\circ} \mathrm{C}$; (c) $700{ }^{\circ} \mathrm{C}$; (d) $800{ }^{\circ} \mathrm{C}$; (e) $900{ }^{\circ} \mathrm{C}$; (f) $1000{ }^{\circ} \mathrm{C}$; (g) $1100{ }^{\circ} \mathrm{C}$ for $1 \mathrm{~h}$.

Finally, it concludes that the studied kaolin-based membrane has comparable characteristics such as surface morphology [41, 83, 86, 91], water absorption, and porosity [41, 44], thermal and mechanical properties [86] with those of commercial kaolin based ceramic membranes. Therefore, the studied kaolin-based membrane is suitable for water purification and desalination applications.

\section{Conclusions}

The raw kaolin has much higher impurities, unlike the commercial kaolin. It is well known that iron-containing minerals impact the optical, chemical, and mineralogical properties of ceramic membranes. However, the treatment processes (beneficiation and acid leaching) can reduce the iron percentage to a lower level to reach the requirement of ceramic membrane for water purification applications. Leaching of iron with oxalic acid solutions at different temperatures, acid concentrations, and leaching time was more effective. Leaching results indicated significant removal of iron oxide ( 2.4 to $0.36 \mathrm{wt} \%$ ) from raw kaolin using $2.0 \mathrm{M}$ oxalic acid at $120^{\circ} \mathrm{C}$ for 120 min contact time. It was possible to raise the kaolin whiteness index (ISO) from 72.0 to $81.4 \%$ with this beneficiation method. The kaolin based ceramic membrane characterization results obtained in this research show that after firing at $1100^{\circ} \mathrm{C}$ the ceramic membrane present: mass loss (11.04 $\left.\pm 0.05 \mathrm{wt} \%\right)$, water absorption $(8.9 \pm 0.4 \%)$, linear shrinkage $(14.5 \pm 0.05 \%)$, and chemical stability (less than $3 \%$ mass loss in acid solution, less than $1 \%$ mass loss in alkali solution), having comparable properties to commercial membranes. Thus, this study could provide new insight into the utilization of beneficiated and acid-leached Ethiopian kaolin for different industrial applications.

\section{Acknowledgments}

The authors would like to thank and appreciate the Ethiopian government/Ministry of Science and Higher Education and the German government for providing laboratory equipment and special thanks to the KU Leuven and the Bahir Dar University, for providing the necessary facilities for this research.

\section{Data availability statement}

All data that support the findings of this study are included within the article (and any supplementary files).

\section{Conflict of interest}

The authors declare that they have no conflict of interest. 


\section{ORCID iDs}

Tsegahun Mekonnen Zewdie (ib) https://orcid.org/0000-0003-3669-5257

\section{References}

[1] Bouzerara F, Harabi A and Condom S 2009 Porous ceramic membranes prepared from kaolin Desalin. Water Treat. 12 415-9

[2] Awad M E et al 2017 Characterization of egyptian kaolins for health-care uses Appl. Clay Sci. 135 176-89

[3] Ayele L et al 2015 Synthesis of zeolite A from Ethiopian kaolin Microporous Mesoporous Mater. 215 29-36

[4] Newns A and Pascoe R D 2002 Influence of path length and slurry velocity on the removal of iron from kaolin using a high gradient magnetic separator Miner. Eng. 15 465-7

[5] Raghavan P et al 2004 Separation of titanoferrous impurities from kaolin by high shear pretreatment and froth flotation Appl. Clay Sci. $25111-20$

[6] Raghavan P et al 2007 Additional investigations on the separation of titanoferrous impurities from kaolin by high shear pretreatment and froth flotation-part I Appl. Clay Sci. 38 33-42

[7] Filippov L O, Dehaine Q and Filippova IV 2016 Rare earths (La, Ce, Nd) and rare metals (Sn, Nb, W) as by-products of kaolin production-part 3: processing of fines using gravity and flotation Miner. Eng. 95 96-106

[8] Larroyd F, Petter C O and Sampaio C H 2002 Purification of north Brazilian kaolin by selective flocculation Miner. Eng. 15 1191-2

[9] Vegliò F et al 1996 Development of a bleaching process for a kaolin of industrial interest by oxalic, ascorbic, and sulfuric acids: Preliminary study using statistical methods of experimental design Ind. Eng. Chem. Res. 35 1680-7

[10] Ambikadevi V R and Lalithambika M 2000 Effect of organic acids on ferric iron removal from iron-stained kaolinite Appl. Clay Sci. 16 $133-45$

[11] Martínez-Luévanos A et al 2011 Leaching kinetics of iron from low grade kaolin by oxalic acid solutions Appl. Clay Sci. 51 473-7

[12] Ocampo-López C, Ramírez-Carmona M E and Vélez-Ortiz E 2013 Thermodynamic analysis of stability in iron removal from kaolin by using oxalic acid Ceramica $59326-30$

[13] Zhu P W et al 2014 Influence of acid leaching and calcination on iron removal of coal kaolin Int. J. Miner. Metall. Mater. $21317-25$

[14] Taran M and Aghaie E 2015 Designing and optimization of separation process of iron impurities from kaolin by oxalic acid in benchscale stirred-tank reactor Appl. Clay Sci. 107 109-16

[15] Lin S M et al 2020 The synergistic mechanisms of citric acid and oxalic acid on the rapid dissolution of kaolinite Appl. Clay Sci. 196 105756

[16] Olvera-Venegas P N, Hernández Cruz L E and Lapidus G T 2017 Leaching of iron oxides from kaolin: Synergistic effect of citratethiosulfate and kinetic analysis Hydrometallurgy 171 16-26

[17] Saikia N J et al 2003 Characterization, beneficiation and utilization of a kaolinite clay from Assam, India Appl. Clay Sci. 24 93-103

[18] Lu M, Xia G and Zhang X 2017 Refinement of industrial kaolin by removal of iron-bearing impurities using thiourea dioxide under mechanical activation Appl. Clay Sci. 141 192-7

[19] Gougazeh M 2018 Removal of iron and titanium contaminants from Jordanian Kaolins by using chemical leaching J. Taibah Univ. Sci. $12247-54$

[20] Caballero I, Colina F G and Costa J 2007 Synthesis of X-type zeolite from dealuminated kaolin by reaction with sulfuric acid at high temperature Ind. Eng. Chem. Res. 46 1029-38

[21] Panda A K et al 2010 Effect of sulphuric acid treatment on the physico-chemical characteristics of kaolin clay Colloids Surfaces A Physicochem Eng. Asp. $36398-104$

[22] Tuncuk A, Ciftlik S and Akcil A 2013 Factorial experiments for iron removal from kaolin by using single and two-step leaching with sulfuric acid Hydrometallurgy 134-135 80-6

[23] Lee S O et al 2006 Study on the kinetics of iron oxide leaching by oxalic acid Int. J. Miner. Process. 80 144-52

[24] Hosseini M R et al 2007 Bioleaching of iron from highly contaminated Kaolin clay by Aspergillus niger Appl. Clay Sci. 37 251-7

[25] Musiał I, Cibis E and Rymowicz W 2011 Designing a process of kaolin bleaching in an oxalic acid enriched medium by Aspergillus niger cultivated on biodiesel-derived waste composed of glycerol and fatty acids Appl. Clay Sci. 52 277-84

[26] Polák Fet al 2019 Fungal bioextraction of iron from kaolin Chem. Pap. 73 3025-9

[27] Xiang H Q, Huang X C and Chen Z L 2011 Influence of organic acids, complexing agents and heavy metals on the bioleaching of iron from kaolin using Fe(III)-reducing bacteria Appl. Clay Sci. 51 478-83

[28] Hosseini M Ret al 2020 Biological separation of quartz from kaolinite using Bacillus licheniformis Sep. Sci. Technol. 55 2061-71

[29] Poorni S and Natarajan K A 2013 Microbially induced selective flocculation of hematite from kaolinite Int. J. Miner. Process. $12592-100$

[30] Hosseini M R and Ahmadi A 2015 Biological beneficiation of kaolin: a review on iron removal Appl. Clay Sci. 107 238-45

[31] Lee E Y, Cho K S, Wook and Ryu H 2002 Microbial refinement of kaolin by iron-reducing bacteria Appl. Clay Sci. 22 47-53

[32] Aragaw T A and Angerasa F T 2020 Synthesis and characterization of Ethiopian kaolin for the removal of basic yellow (BY 28) dye from aqueous solution as a potential adsorbent Heliyon $6 \mathrm{e} 04975$

[33] Mustapha S et al 2019 Potential of using kaolin as a natural adsorbent for the removal of pollutants from tannery wastewater Heliyon 5 e02923

[34] Mamudu A et al 2020 Parametric investigation of indigenous Nigeria mineral clay (Kaolin and Bentonite) as a filler in the Fluid Catalytic Cracking Unit (FCCU) of a petroleum refinery Alexandria Eng. J. 595207-17

[35] Awad M E et al 2017 Kaolinite in pharmaceutics and biomedicine Int. J. Pharm. 533 34-48

[36] Romero-Guerrero L M et al 2018 Chemical, mineralogical, and refractory characterization of kaolin in the regions of HuayacocotlaAlumbres, Mexico Adv. Mater. Sci. Eng. 20188156812

[37] Elgamouz A et al 2019 Characterization of the firing behaviour of an illite-kaolinite clay mineral and its potential use as membrane support Heliyon 5 e 02281

[38] Elgamouz A and Tijani N 2018 From a naturally occurring-clay mineral to the production of porous ceramic membranes Microporous Mesoporous Mater. 271 52-8

[39] Kharbish S and Farhat H I 2017 Mineralogy and physico-chemical properties of Wadi Badaa clays (Cairo-Suez district, Egypt): a prospective resource for the ceramics industry Arab J Geosci 10 1-10

[40] Mustapha S et al 2021 Fabrication of porous ceramic pot filters for adsorptive removal of pollutants in tannery wastewater Sci. African $11 \mathrm{e} 00705$ 
[41] Sahnoun R D and Baklouti S 2013 Characterization of flat ceramic membrane supports prepared with kaolin-phosphoric acid-starch Appl. Clay Sci. 83-84 399-404

[42] Senoussi H et al 2016 Mineralogical and chemical characterization of DD3 kaolin from the east of Algeria Bol la Soc Esp Ceram $y$ Vidr 55 $121-6$

[43] Kar B et al 2013 Characterization and beneficiation studies for the removal of iron from a china clay from India Clay Miner. 48 $759-69$

[44] Merga A et al 2019 Fabrication of electrical porcelain insulator from ceramic raw materials of Oromia region, Ethiopia Heliyon 5 e02327

[45] Gazagnes Let al 2007 Desalination of sodium chloride solutions and seawater with hydrophobic ceramic membranes Desalination 217 260-6

[46] Cui Z et al 2011 Pilot study on the ceramic membrane pre-treatment for seawater desalination with reverse osmosis in Tianjin Bohai Bay Desalination 279 190-4

[47] Dramas L and Croué J P 2013 Ceramic membrane as a pretreatment for reverse osmosis: Interaction between marine organic matter and metal oxides Desalin. Water Treat. 51 1781-9

[48] He M et al 2020 Novel polydopamine/metal organic framework thin film nanocomposite forward osmosis membrane for salt rejection and heavy metal removal Chem. Eng. J. 389124452

[49] You S et al 2017 Rejection of heavy metals in acidic wastewater by a novel thin-film inorganic forward osmosis membrane Chem. Eng. J. $320532-8$

[50] Kujawa J, Cerneaux S and Kujawski W 2015 Removal of hazardous volatile organic compounds from water by vacuum pervaporation with hydrophobic ceramic membranes J. Memb. Sci. 474 11-9

[51] Mora-Gómez J et al 2017 Anion transport through ceramic electrodialysis membranes made with hydrated cerium dioxide J. Am. Ceram. Soc. 100 4180-9

[52] Das R et al 2016 Development of hydrophobic clay-alumina based capillary membrane for desalination of brine by membrane distillation J. Asian Ceram. Soc. 4243-51

[53] Hubadillah S K et al 2019 Hydrophobic ceramic membrane for membrane distillation: A mini review on preparation, characterization, and applications Sep. Purif. Technol. 217 71-84

[54] Khemakhem S and Amar R B 2011 Modification of tunisian clay membrane surface by silane grafting: application for desalination with air gap membrane distillation process Colloids Surfaces A Physicochem Eng Asp 387 79-85

[55] Wang J W et al $2016 \beta$-Sialon ceramic hollow fiber membranes with high strength and low thermal conductivity for membrane distillation J. Eur. Ceram. Soc. 36 59-65

[56] Costo R et al 2019 Improving the reliability of the iron concentration quantification for iron oxide nanoparticle suspensions: a twoinstitutions study Anal Bioanal Chem 411 1895-903

[57] Ibrahim K M, Moumani M K and Mohammad S K 2018 Extraction of $\gamma$-alumina from low-cost kaolin Resources 463

[58] Wang N et al 2018 Enrichment of Niobium and Titanium from Kaolin Using an Acid-Alkali Leaching Process Metall. Mater. Trans. B 493552-8

[59] Scorzelli R B et al 2008 Spectroscopic studies of kaolin from different Brazilian regions Clay Miner. 43 129-35

[60] Olaremu A G 2015 Physico-Chemical Characterization of Akoko Mined Kaolin Clay J. Miner. Mater. Charact. Eng. 03 353-61

[61] Wang Het al 2011 Characterization and thermal behavior of kaolin J. Therm. Anal. Calorim. 105 157-60

[62] Güneyisi E et al 2012 Microstructural properties and pozzolanic activity of calcined kaolins as supplementary cementing materials Can. J. Civ. Eng. 39 1274-84

[63] Bukalo N N et al 2017 Geochemistry of Selected Kaolins from Cameroon and Nigeria Open Geosci 9 600-12

[64] Garcia-Valles Met al 2020 Mineralogical and thermal characterization orf kaolinitic clays from terra alta (Catalonia, Spain) Minerals 10142

[65] Douiri H et al 2017 Structural and dielectric comparative studies of geopolymers prepared with metakaolin and Tunisian natural clay Appl. Clay Sci. 139 40-4

[66] Behnamfard A et al 2019 The effect of thermal and acid treatment of kaolin on its ability for cyanide removal from aqueous solutions Environ. Earth Sci. 78 1-12

[67] El Alouani M et al 2019 Preparation, characterization, and application of metakaolin-based geopolymer for removal of methylene blue from aqueous solution J. Chem. $10483-507$

[68] Fakhfakh S et al 2010 Elaboration and characterisation of low cost ceramic support membrane Adv. Appl. Ceram 10931-8

[69] Issaoui M et al 2016 Design and characterization of flat membrane supports elaborated from kaolin and aluminum powders Comptes Rendus Chim 19496-504

[70] Mbaye A et al 2014 Characterization of natural and chemically modified kaolinite from Mako (Senegal) to remove lead from aqueous solutions Clay Miner. 49527-39

[71] Bouzid Rekik S et al 2017 Study of ceramic membrane from naturally occurring-kaolin clays for microfiltration applications Period. Polytech. Chem. Eng. 61 206-15

[72] Septiani S et al 2019 Production of ceramic membrane based on acid- and alkali-activated metakaolinite as cooling material for monocrystalline silicon solar cell J. Kim. Val. 5 159-68

[73] Saikia B J and Parthasarathy G 2010 Fourier transform infrared spectroscopic characterization of kaolinite from Assam and Meghalaya, Northeastern India J. Mod. Phys. 01 206-10

[74] Zhang Het al 2015 Equilibrium, kinetic and thermodynamic studies of adsorption of Th(IV) from aqueous solution onto kaolin J. Radioanal. Nucl. Chem. 303 87-97

[75] Sarma G K, Sen Gupta S and Bhattacharyya K G 2019 Removal of hazardous basic dyes from aqueous solution by adsorption onto kaolinite and acid-treated kaolinite: kinetics, isotherm and mechanistic study SNAppl. Sci. 1 1-15

[76] Clausi M et al 2016 Metakaolin as a precursor of materials for applications in Cultural Heritage: Geopolymer-based mortars with ornamental stone aggregates Appl. Clay Sci. 132-133 589-99

[77] Lee S O et al 2007 Dissolution of iron oxide using oxalic acid Hydrometallurgy 87 91-9

[78] Pariyan Ket al 2020 Optimization and kinetics of oxalic acid treatment of feldspar for removing the iron oxide impurities Sep. Sci. Technol. 55 1871-82

[79] Fiori C et al 1989 Mineralogical composition of the clay bodies used in the Italian tile industry Appl. Clay Sci.4461-73

[80] Mardare C C et al 2003 Deposition of bioactive glass-ceramic thin-films by RF magnetron sputtering J. Eur. Ceram. Soc. 23 1027-30

[81] Monteiro S N and Vieira C M F 2004 Influence of firing temperature on the ceramic properties of clays from Campos dos Goytacazes, Brazil Appl. Clay Sci. 27 229-34

[82] Vasanth D, Uppaluri R and Pugazhenthi G 2011 Influence of sintering temperature on the properties of porous ceramic support prepared by uniaxial dry compaction method using low-cost raw materials for membrane applications Sep. Sci. Technol. 46 1241-9 
[83] Nkoumbou C et al 2009 Kaolin from Mayouom (Western Cameroon): Industrial suitability evaluation Appl. Clay Sci. 43 118-24

[84] Owoeye S S et al 2019 Influence of waste glasses on the physico-mechanical behavior of porcelain ceramics Bol. la Soc. Esp. Ceram y Vidr. $5877-84$

[85] Abubakar M et al 2020 Influence of firing temperature on the physical, thermal and microstructural properties of kankara kaolin clay: a preliminary investigation Materials (Basel) 13 1-8

[86] Kamoun N, Jamoussi F and Rodríguez M A 2020 The preparation of meso-porous membranes from Tunisian clay Bol la Soc. Esp. Ceram $y$ Vidr 59 25-30

[87] Wimuktiwan P et al 2020 Influence of the addition of pore foaming agent on mechanical and thermal properties of porcelain tiles Ceram-Silikaty $64164-71$

[88] Elomari H et al 2016 Elaboration and characterization of flat membrane supports from Moroccan clays. Application for the treatment of wastewater Desalin. Water Treat. 57 20298-306

[89] Malik N, Bulasara V K and Basu S 2020 Preparation of novel porous ceramic microfiltration membranes from fly ash, kaolin and dolomite mixtures Ceram. Int. 46 6889-98

[90] Tatar I, Ediz N and Aydln A 2017 Optimum parameters for the production of porous ceramic materials J. Aust. Ceram. Soc. 53 253-63

[91] Eom J H, Kim Y W and Song I H 2013 Processing of kaolin-based microfiltration membranes J. Korean Ceram Soc. 50 $341-7$

[92] Hedfi I et al 2014 The preparation of micro-porous membrane from a Tunisian kaolin Appl. Clay Sci. 101 574-8

[93] Hedfi I et al 2016 Preparation of macroporous membrane using natural Kaolin and Tunisian lignite as a pore-forming agent Desalin. Water Treat. 57 13388-93

[94] Hubadillah S K et al 2017 Superhydrophilic, low cost kaolin-based hollow fibre membranes for efficient oily-wastewater separation Mater. Lett. 191 119-22

[95] Nguiamba N et al 2019 Physico-Chemical Characterization and Stability Study in Acidic and Basic Solution of Ceramic Filters from Mouka's Clay (Cameroon) J. Mater. Sci. Chem. Eng. 07 42-53

[96] Saikia J et al 2019 Preparation and characterization of low cost flat ceramic membranes from easily available potters' clay for dye separation Bull. Mater. Sci. 42 1-13

[97] Obada D O et al 2017 Physico-mechanical and gas permeability characteristics of kaolin based ceramic membranes prepared with a new pore-forming agent Appl. Clay Sci. 150 175-83

[98] Kadiri C et al 2020 Preparation and properties of tubular macroporous ceramic membrane supports based on natural quartz sand and dolomite J. Aust. Ceram. Soc. 56 379-87

[99] Nandi B K, Uppaluri R and Purkait M K 2008 Preparation and characterization of low cost ceramic membranes for micro-filtration applications Appl. Clay Sci. 42 102-10 